\title{
Trace elements: critical insights from 15 years of monitoring in the Venice Lagoon catchment basin (Italy)
}

\author{
Grazia Soccio • Roberto Lava • Marco Ostoich • \\ Francesca Zanon • Maurizio Marchiori • Nadia Rado • \\ Emiliano Coraluppi • Antonio Marcomini
}

Received: 21 December 2017 / Accepted: 2 October 2018 / Published online: 18 October 2018

(C) Springer Nature Switzerland AG 2018

\begin{abstract}
The study focused on selected trace elements (As, $\mathrm{Cd}, \mathrm{Cr}, \mathrm{Hg}, \mathrm{Ni}, \mathrm{Pb}$ ) monitored in surface waters of the Venice Lagoon catchment basin (North East Italy) over the period 2000-2015. The monitoring was undertaken to verify the achievement of the quality objectives set by the European and national legislations. The available results have been analyzed to evaluate the chemical status of water bodies. The limit of quantification (LOQ) of the applied analytic techniques appears critical for the adequate water monitoring; for some parameters, the percentage of not visible values due to non-satisfactory LOQ was higher in the beginning of the period; the subsequent improvement of LOQ allowed assessing the respect of environmental quality standards (EQSs). The study analyzes time trends in single stations and the differences between detected concentrations in the
\end{abstract}

Electronic supplementary material The online version of this article (https://doi.org/10.1007/s10661-018-7032-5) contains supplementary material, which is available to authorized users.

G. Soccio · A. Marcomini

Department of Environmental Sciences, Informatics and Statistics, University Ca' Foscari of Venice, Via Torino n. 155,

30172 Mestre-Venice, Italy

R. Lava $\cdot$ F. Zanon $\cdot$ M. Marchiori $\cdot$ N. Rado $\cdot$ E. Coraluppi Laboratory Department, Veneto Regional Environmental Prevention and Protection Agency (ARPAV), Via Lissa 6, 30174 Mestre-Venice, Italy

M. Ostoich $(\bowtie)$

Provincial Department of Venice, Veneto Regional Environmental Prevention and Protection Agency (ARPAV), Via Lissa 6,

30174 Mestre-Venice, Italy

e-mail: marco.ostoich@arpa.veneto.it considered stations. Moreover, maximum concentrations and water flows have been considered to understand the potential correlation. Cumulated frequency curves for the most critical parameters have been built to identify situation of potential overtaking of the EQSs in force. The most polluted sampling stations of the drainage basin for the six trace elements were found in Cuori and Fiumazzo rivers. Although LOQs changed over time, the recorded trends show a quality improvement and a good compliance with respect to EQSs set by European legislation, while considering EQSs set by local special legislation, the objectives are not yet satisfied. Arsenic is ubiquitous; thus, it can be supposed to be originated as a background environmental concentration, while nickel appears of industrial origin according to its point and local presence.

Keywords Venice Lagoon · Trace metals . Environmental quality standards (EQS) $\cdot$ Limit of quantification (LOQ) · Chemical status · Cumulated frequency distribution

\section{Introduction}

Due to its vital value for life, water is required clean and free of pathogenic microorganisms and/or hazardous chemicals. Among chemicals, trace elements (i.e., metals) are very toxic to human beings (Migahed et al. 2016), depending on the type of metal, exposure time, concentration, and degree of bioaccumulation in the food chain. Moreover, high contamination levels can 
seriously affect ecosystems compromising metabolic activities and community diversity (Masiol et al. 2014). The environmental and human exposure to trace elements received special attention by national environmental agencies (Granero and Domingo 2002): its reduction is necessary to protect humans and to support environmental conservation and recovery. However, naturally occurring (background) concentrations can vary significantly depending on local geological features, and universal thresholds cannot be established (Ridgway et al. 2003). Therefore, the assessment of actual pollution levels and the identification of appropriate management policies may be difficult (Masiol et al. 2014). Many studies dealt with assessment of metals pollution in coastal areas or river catchments worldwide, focusing especially on trace elements in sediments in Europe (Alharbi and El-Sorogy 2017) (Charizopoulos et al. 2016; Couto et al. 2018; Nagy et al. 2016; Rodriguez et al. 2018) and worldwide (Batbayar et al. 2017; De Carvalho Aguiar et al. 2018; Vystavna et al. 2018).

Regulatory actions were undertaken by most industrialized countries in order to minimize the environmental occurrence of these elements (Granero and Domingo 2002; Nesto et al. 2007) (Allan 2012). In Europe, the Water Framework Directive (WFD; EC 2000) requires the achievement of a good ecological status by the year 2020 and the chemical status must be good with reference to environmental quality standards (EQSs) fixed for dangerous substances and priority and priority hazardous substances, including trace elements (list from Decision 2455/2001/EEC, Directive 2008/105/EEC and Directive 2013/39/EU; EC 2001, 2008, 2013). The WFD asks for an initial assessment and classification of natural waters according to their ecological and chemical status, and the subsequent implementation of monitoring programs in order to enable member states to repeat periodically the status evaluation and verify the achievement of the environmental targets (Pastres and Solidoro 2012) (Vlachopoulou et al. 2014).

The Venice Lagoon and its drainage basin (North East of Italy, the survey area) are one of the world's best-known examples of ecosystem that has undergone dramatic configurational and compositional changes due to human influence for several hundred years (Guerzoni et al. 2007). The drainage basin is that part of the mainland constituted of an ensemble of tributary sub-basins with different morphological characteristics, extension, and freshwater fluxes, which have a fundamental role for the transfer of water, solid matter, and pollutants, such as metals analyzed in this study, into the Lagoon (Zonta et al. 2005). The drainage basin of Venice Lagoon (Fig. 1) includes (i) the four provinces of Venice, Padua, Treviso, and Vicenza in the Veneto Region located between the NE-verging northern Apennine and the SSE-verging eastern South-Alpine chains (Zecchin et al. 2009) and (ii) a total of 108 municipalities. It covers an area of approximately $2038 \mathrm{~km}^{2}$ whose surface water network of more than $2500 \mathrm{~km}$ discharges, under normal flow conditions, into the Venice Lagoon $\left(550 \mathrm{~km}^{2}\right)$. The outflow of the drainage waters of the entire basin occurs either naturally or through water mechanical systems that spread across the lagoon environment in 27 different discharge points. Water pollution comes from point and non-point sources, and controlled and uncontrolled discharges related to several anthropogenic pressures (Bernardello et al. 2006). Also, the underground geological systems and the direct rainfalls feed the lagoon watershed. In result, contaminants are unevenly distributed with large hot-spots located mainly in the surroundings of main lagoon tributaries mouths (Micheletti et al. 2007).

Over the last 50 years, the morphology and the quality of water and sediments of the Venice Lagoon underwent significant changes, which were directly or indirectly induced by the industrial and agricultural development (Pastres et al. 2004) (Deheyn and Shaffer 2007). During the last 20 years, several lagoon-scale monitoring studies and international, national, and regional research projects have been carried out to assess the quality status of the lagoon environment, to support its sustainable management and, more recently, to cope with the WFD requirements (Micheletti et al. 2011). In order to evaluate the degree of pollution in the lagoon, research started in 1977 focusing on sediment as suitable indicator of pollution in shallow aquatic environments (Pavoni et al. 1987). Concentrations of trace elements in the sediment of the whole lagoon are known since 1997, when an extensive survey on sediment quality was carried out (Carrer et al. 2005). The knowledge of the spatial distribution of trace metals by sampling surface sediments (covering the whole lagoon or selected areas) with the study of temporal variations in contamination by analyzing radio-dated cores can provide information on source and on historical development of pollution as well as reliable estimates of metal fluxes (Bernardello et al. 2006). Further monitoring activities focused on (i) measurement of contamination levels in the various environmental matrixes 


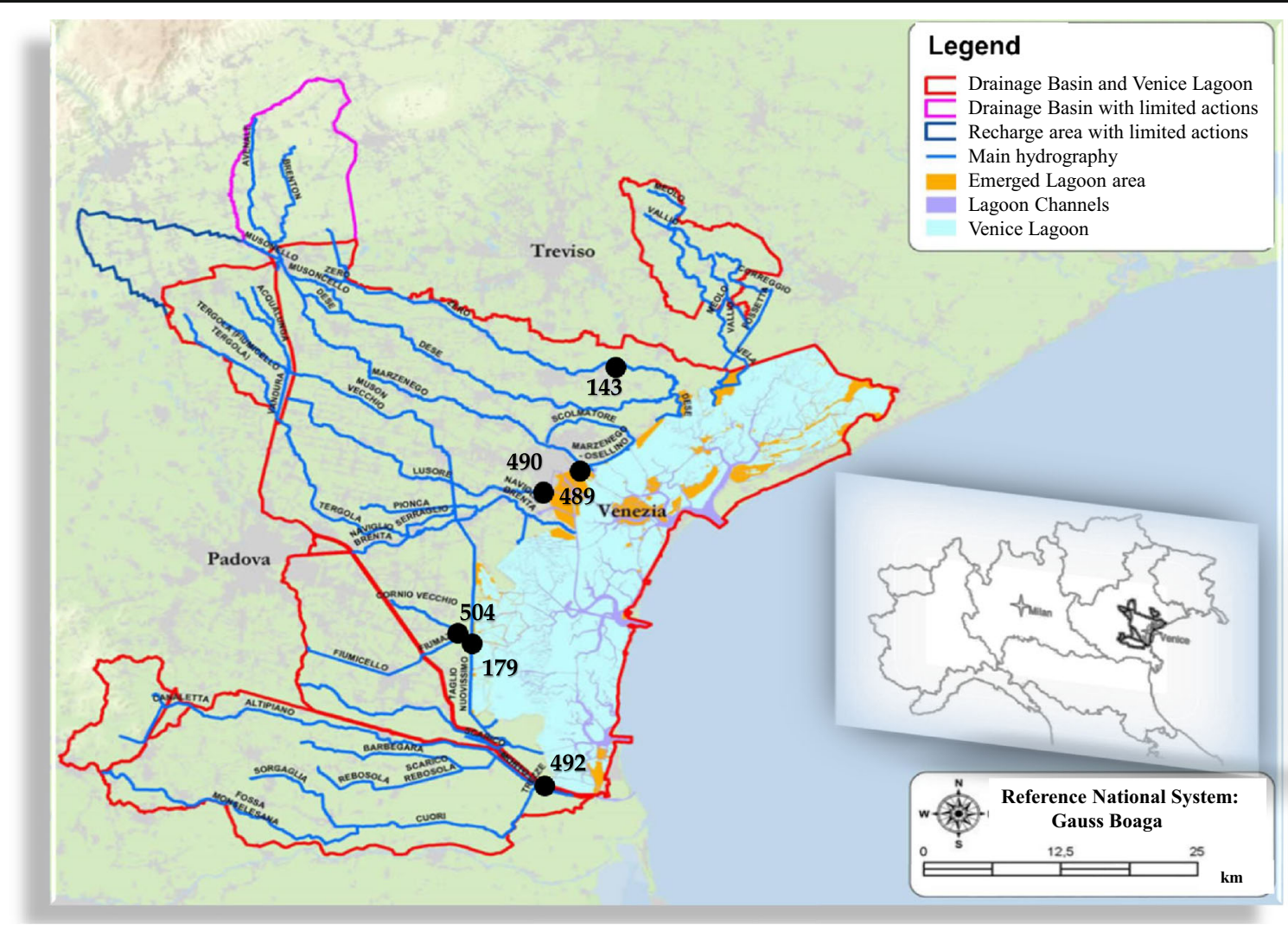

Fig. 1 Sampling stations in the Venice Lagoon catchment area and surface water-monitoring station considered for the study: \#143 (Zero), \#492 (Cuori), \#489 (Marzenego-Osellino), \#490 (Lusore), \#179 (Fiumazzo), \#504 (Novissimo)

(sediments, waters, organisms); (ii) evaluation of pollutant loadings into the lagoon ecosystem (atmospheric depositions; loads from the watershed; direct discharges, particularly from the industrial area of Porto Marghera) (Carrer et al. 2005) (Cacciatore et al. 2016). The environmental monitoring plans initially were focused mostly on the central part of the lagoon, which was the most heavily polluted, due to the presence of the discharges of the industrial area of Porto Marghera. Since 2000, in agreement with the Venice Water Authority (Italian Ministry of Infrastructure and Transports), an integrated monitoring plan has been launched throughout the watershed of the Venice Lagoon carried out in a network of manual and automatic sampling stations, to meet the regulatory obligations (Pastres et al. 2004).

Then, since 1998, EQSs have been defined and applied and very strict discharge limits have been fixed in the Venice Lagoon and in its catchment area. Monitoring stations were located at the mouth of main rivers flowing into the Venice Lagoon and the following trace elements, among other contaminants, were systematically measured: arsenic, cadmium, chrome, mercury, nickel, and lead.
The study presented here has been carried out by the Veneto Regional Environmental Protection Agency (ARPAV), Provincial Department of Venice, and is part of a more extensive program aimed at the classification of the chemical status of the Venice Lagoon over 2000 2015 period, according to the WFD (EC 2000). The implementation of the WFD and more restrictive environmental regulations during the considered 15 years required major analytical effort in order to achieve adequate limits of quantification (LOQs). Lower LOQs, acceptable to guarantee the measurement of the new EQSs fixed with the special regulation for Venice Lagoon and the new standards fixed with Directives 2008/105/EC (EC 2008) and 2013/39/EC (EC 2013), required the optimization of the existing methods, sometimes changing completely the analytical techniques.

The objectives of this study were (1) to collect monitoring data on the Venice Lagoon watershed; (2) to analyze available data related to the studied trace elements (As, $\mathrm{Cd}, \mathrm{Cr}, \mathrm{Hg}, \mathrm{Ni}, \mathrm{Pb}$ ) to assess the time course of environmental quality in selected sampling stations; and (3) to compare the concentrations of examined trace 
elements in freshwaters with regulatory threshold values and/or quality objectives introduced by EU and local legislations for a preliminary risk approach.

\section{Materials and methods}

The study area and the surface water-monitoring network

Twelve river mouth monitoring stations representative of the lagoon tributaries were initially assessed and six of them selected for this study. Their location is reported in Fig. 1. The sampling stations \#143 (Zero River in catchment area of Dese, location Quarto d'Altino), \#489 (Marzenego-Osellino River, location Mestre-Venice), and \#490 (Lusore Drain, location Marghera-Venice) are located in Northern Lagoon. Zero station, whose year of activation dates back to 1988 , has a distance from the river mouth of $8.7 \mathrm{~km}$ unlike the stations Marzenego-Osellino and Lusore that have been activated both in 2001 and with a distance from the river mouth of $1.5 \mathrm{~km}$. Both stations \#179 (Fiumazzo Drain in catchment area of Fiumicello-VI Presa) and \#504 (Novissimo Channel in catchment area of Naviglio Brenta) are related to the Central Lagoon and located in the municipality of Campagna Lupia. Their distance from the river mouth varies from $0.6 \mathrm{~km}$ (station \#179, activated in the year 1988) to $11.0 \mathrm{~km}$ (station \#504, activated during the 2003). Finally, Cuori Channel (Station \#492, activated in 2001) in the catchment area of Bonifica Adige Bacchiglione, located in Chioggia, is the only station between the ones of our interest linked to the South Lagoon with a distance from the river mouth of $1.4 \mathrm{~km}$. The river mouth sampling stations are important primarily for the definition of the environmental quality status of water bodies both for the Italian Decree n. 152/2006 and the special local regulation of Venice Lagoon.

European, national, and local regulatory framework for the Venice Lagoon catchment area

The implementation of the WFD forces chemical monitoring of priority pollutant concentrations to ensure the protection and enhancement of coastal ecosystems within the EU. The WFD requires member states to gain a better understanding on how these pollutants affect surface waters in order to determine pollution control options (Martí et al. 2011). For dealing with water pollution caused by contaminants, a list of priority substances was adopted (Decision 2455/2001/EC, EC 2001) identifying 33 substances or groups of substances of priority concern in EU surface waters due to their widespread use and their high concentrations in rivers, lakes, and transitional and coastal waters. The priority substances (characterized by high toxicity, high environmental persistence, or high tendency to bioaccumulate) are responsible for a significant risk to or through the aquatic environment, including the risks associated with the use of surface water for drinking water production (Martí et al. 2011).

This list includes four metals $(\mathrm{Cd}, \mathrm{Hg}, \mathrm{Ni}$, and $\mathrm{Pb})$ and must be reviewed every 4 years and updated as appropriate (Lepom et al. 2009); it has recently been revised with the Directive 2013/39/EU (EC 2013) and new priority substances were added for a total of 45 pollutants. Twelve of these substances (e.g., $\mathrm{Cd}$ and $\mathrm{Hg}$ ) are presently indicated as priority hazardous substances and are characterized by persistence and bioaccumulability, subjected to the cessation or phasing out of discharges, emissions, and losses in 20 years (EC 2000; Cesa et al. 2013). Hence, EQSs for priority substances and other selected pollutants and related compliance checking provisions have been established for inland surface waters (rivers and lakes) and for other surface waters (transitional, coastal, and territorial waters). Two EQS values have been set for water: (i) annual average concentrations (AA-EQS), based on monthly measurements, for protection against long-term and chronic effects and (ii) maximum allowable concentrations (MAC-EQS), measured in the precise point (only for some substances characterized by seasonal discharges) to avoid serious irreversible consequences for ecosystems due to acute exposure in the short term (Lepom et al. 2009). In the case of metals, the EQSs refer to the dissolved concentration, i.e., the concentration in the liquid phase of a water sample obtained by filtration through a $0.45-\mu \mathrm{m}$ filter or any equivalent pre-treatment. For metals, the compliance regime is adapted by allowing member states to take natural background levels and bioavailability affected by hardness, $\mathrm{pH}$, or other water quality parameters into account (Lepom et al. 2009). The national list of pollutants according to WFD and daughter directives implementation is the Italian Decree n. 152/2006.

Since 1998, the Venice Lagoon and its catchment have a specific local regulation that establishes water quality standards and discharge limit in many cases stricter than EU level (i.e., Italian Decree of the Ministry 
of Environment 23/04/1998 on water EQS and Italian Decree 30/07/1999 on limit values for discharges into the Venice Lagoon and its watershed, so-called Ronchi-Costa decrees). These local legislations include also references for $\mathrm{Cr}$ and As parameters. Moreover, with the special legislation on Venice Lagoon, the prohibition of discharges of specific substances (Italian Decree 16/12/1998) and the set of the maximum admissible pollution loads (Italian Decree 9/02/1999) have been established. Consequently, the legal management framework adopted for the Venice Lagoon and its catchment basin anticipated the "combined approach" required by the WFD (art. 10 as new approach to dangerous, priority, and priority hazardous substances. The Italian Decree of the Ministry of Environment 23/04/ 1998 fixed specific EQSs for the freshwater flowing into the Venice Lagoon, the regulation on discharge limit values (Italian Decree 30/07/1999) also established the analytical techniques to be used for monitoring, together with their attainable LOQs. Definitely, the EQSs established with the local regulation appear more restrictive, ambitious, and difficult to be achieved than European list for the considered parameters and in this sense, the Venice case study appears an important and unique pilot experience at national as well international level in the control of dangerous, priority, and priority hazardous substances in surface water bodies and wastewater effluents (Ostoich et al. 2009). Before 1998, the Italian Decree n. 962/1973 concerning the protection of the city of Venice and its territory by water pollution imposed limit values in milligrams per liter for effluents discharged into the current waters. These old values were even 2-3 orders of magnitude higher, i.e., As maximum concentration $0.2 \mathrm{mg} / \mathrm{L} ; \mathrm{Cd} 0.02 \mathrm{mg} / \mathrm{L} ; \mathrm{Cr}$ (III) $1.0 \mathrm{mg} / \mathrm{L}$; Cr (VI) $0.1 \mathrm{mg} / \mathrm{L} ; \mathrm{Hg} 0.01 \mathrm{mg} / \mathrm{L} ; \mathrm{Ni}$ $2.0 \mathrm{mg} / \mathrm{L}$; and $\mathrm{Pb} 0.1 \mathrm{mg} / \mathrm{L}$. Table 1 shows the EQSs from EU Directives for the selected parameters compared with the values of the special local regulation in force for the Venice Lagoon (quality standards and discharge limit values), including the applied analytical techniques for trace elements and the LOQs achieved during the years according to analytical improvements.

The evaluation of the chemical status, object of study in this project, takes into account both the EU legislation and the special legislation for Venice, presented as a local specific case with international relevance because of its sensitivity and the strong effort to develop an approach to guarantee sustainable pollution loads.
Monitoring and sampling procedures

To control and reduce pollution entering the lagoon a systematic monitoring network has been established. The availability of a long time series of monitoring data has allowed assessing the relationships between the exchange factors on the ecosystem and their direct and indirect effects, developing a conceptual scheme of water quality trend over decades (Solidoro et al. 2010).

The monitoring campaigns have been carried out between years 2000 and 2015 by the Veneto Regional Environmental Protection Agency and recorded in the Regional Environmental Information System of Veneto (SIRAV). The concentration values regard six trace elements (As, $\mathrm{Cd}, \mathrm{Cr}, \mathrm{Hg}, \mathrm{Ni}, \mathrm{Pb}$ ) monitored in the selected stations; all the parameters have been determined in the dissolved and in the total forms, even if for this study only the dissolved form is taken into account. For the monitoring activity, 3 to 12 samples per year with irregular frequency (annual sampling interval, about 14 months) have been collected. The frequency varies depending on year, availability of sample, analytical conditions, and importance of the station. The WFD does not mandate the use of a particular set of methods and spot sampling is currently the most commonly used method for measuring chemical pollutants. However, this method provides only point results gathered at the instant of sampling and could prevent the assessment of episodic or intermittent events, when concentrations widely fluctuate in space and time. During the considered years, ARPAV laboratories in Venice carried out the experimental part. Sampling, shipping to the laboratory and storage conditions were hence performed according to EN ISO 5667-3 (ISO 5667 1994) and following revisions. Samples were analyzed as soon as possible or eventually stored overnight at $4{ }^{\circ} \mathrm{C}$. General parameters like temperature and $\mathrm{pH}$ were measured on-field, while conductivity, hardness, and salinity were performed as soon as samples arrived in the laboratory. Conductivity measures were performed using a Radiometer analytical CDM210 by Hach (Loveland, CO, USA) equipped with a conductivity cell with temperature probe Radiometer CDC641T and an LOQ of $1 \mu \mathrm{S} / \mathrm{cm}$.

\section{Quantitative determination of trace elements}

The analytical procedures used for the determination of metals in waters have been developed and validated according to standard procedure ISO 17025 (ISO-IEC 


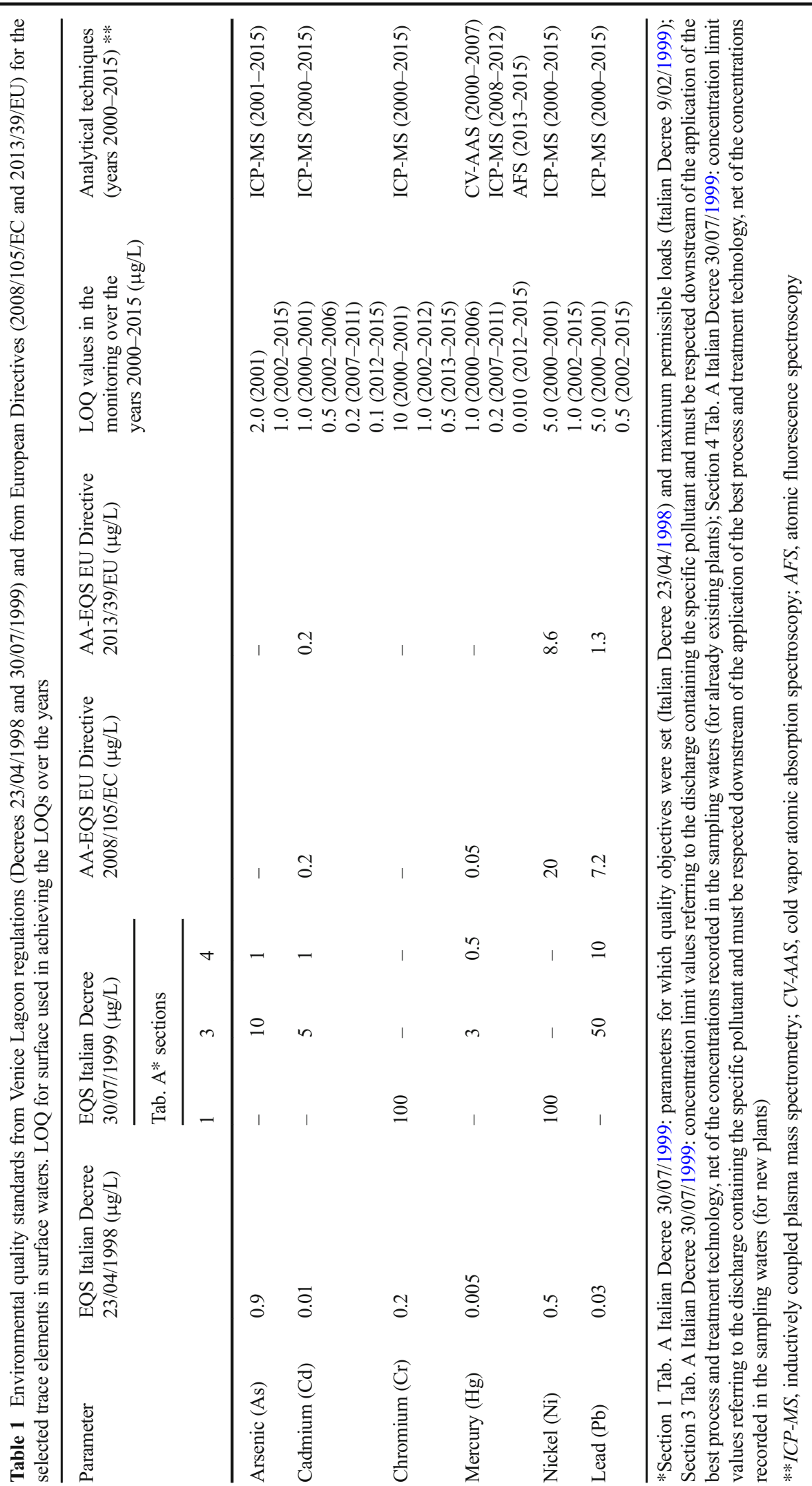


2005). For the determination of the dissolved fraction, the samples were filtered through $0.45 \mu \mathrm{m}$ cellulose acetate (Sartorious, Goëttingen, Germany) then acidified adding $1 \mathrm{~mL}$ of nitric acid $\left(\mathrm{HNO}_{3}\right)$ from Merck (Darmstadt, Germany) and subsequently analyzed with the techniques reported in Table 1 . Analytical techniques used over the years 2000-2015 to achieve the LOQs values were (i) during 2000-2010, ICP-MS ELAN Perkin Elmer (Waltham, MA US); (ii) during 2011-2012, ICP-MS Mod 820 MS Varian (Palo Alto, CA US); (iii) during 2013-2015, ICP-MS Mod 7700 Agilent (Santa Clara, CA US); (iv) for Hg during 20002015, CV-AAS FIMS Perkin Elmer; and (v) for $\mathrm{Hg}$ during 2012-2015, AFS MERCUR Analytik Jena (Jena, Germany).

In the case of waters with conductivity higher than $3000 \mu \mathrm{S} \mathrm{cm}^{-1}$, the procedure also involves further dilution with ultrapure water; in Tab. SM1, the range of variation of this parameter is reported for the chosen six monitoring stations. During the 15 years of the study, a considerable improvement of the analytical techniques was achieved with a subsequent update of the best available techniques to determine the trace elements. The LOQ, considered for this assessment, is the minimum level at which an analyte can be quantitatively determined with a precision and accuracy acceptable by the protocol in use. The WFD does not report the specific analytical techniques but indicates some minimum quality criteria to apply at the validated method, i.e., LOQ equal or lower than the $30 \%$ of AA-EQS and an uncertainty of the measure lower than $50 \%$ at the AA-EQS (EC 2009; Cesa et al. 2013). The different LOQs improved during the years are highlighted in Table 1. The improvement of the analytical protocols (i.e., lowering LOQs) has been achieved in different steps due to upgrade of the selected techniques in terms of (i) revising of protocols from internal procedure to standardized official methods and (ii) upgrading of best available technologies and analytical instrumentations (e.g., interference suppression using of reaction cell and collision chamber with the ICP-MS). This analytical approach, according to systematic monitoring in the sampling stations of Fig. 1, has allowed following over the time the concentrations for the dissolved fraction of the six selected elements in the period 2000-2015. Over the 15 years, the procedures applied were constantly under QA/QC using certified reference materials mainly produced by the National Research Council of Canada and participating regularly at inter-calibration exercises organized by accredited bodies like UNICHIM (Italy), IFA (Austria), and LGC (UK). Moreover, the standard calibration and the analysis of an adequate number of quality control samples were performed for every batch of analysis.

Cumulated frequency distribution and comparison with EQS

In this study, EQSs in force for the case study area (the Venice Lagoon catchment) are compared to monitored concentrations in order to identify potential stations at higher concern from environmental exposure to selected trace elements ( $\mathrm{As}, \mathrm{Cd}, \mathrm{Cr}, \mathrm{Hg}, \mathrm{Ni}, \mathrm{Pb}$ ) to identify further research and the application of further analysis via the application of a risk assessment procedure (Suter 2000). The comparison between monitored concentrations and EQS (Italian Decree of the Ministry of Environment 23/04/1998, Italian Decree 30/07/1999 and WFD 2000/60/EC) is performed, where detected concentrations in the Venice Lagoon catchment are compared to EQS in force by means of cumulative relative frequency distribution of the monitored values. If $f(x i)$ is the absolute frequency of observations on a discrete variable, then the absolute cumulated frequency (or number) of observations not exceeding that value is called the absolute cumulated frequency: $F(x i)=\operatorname{SUM}(f(x i))$. The proportion of observations taking on a specific value or falling into a specific class is called the relative cumulated frequency, the absolute frequency standardized by the total number of observations (Härdle et al. 2015).

Through the relative cumulated frequency, it is possible to explicit the rate at which the cumulative distributions reach the value of $100 \%$. Specifically, higher rates are achieved with lower concentrations and lower rates with higher concentrations. Each empirical distribution (also known as cumulative probability or cumulative distribution, realized starting from monthly averages of the concentration values available from institutional monitoring) is peculiar of each sampling station analyzed and encloses information about data dispersion. Depending on the spread, it is possible to obtain an assessment of the entity and distribution of the observed contamination phenomenon. Comparisons with EQSs and discharge limit values have been carried taking into consideration both European and local regulations. In particular, more stringent EQS have been introduced at European level with the daughter's directives 2008/105/ EC (EC 2008) and 2013/39/EU (EC 2013) and at local 
level as set by the local regulations (Italian Decrees 23/ $04 / 1998$ and 30/07/1999). In this way, the critical parameters can be identified and then adequately monitored. The monitoring of these parameters must be intensified by means of investigative monitoring, in accordance with the WFD so that the sources can be identified and adequate measures for the reduction or elimination of the substances of concern can be taken, in accordance with the WFD objectives (Ostoich et al. 2009).

The software package "Excel" has been used for the statistical treatment (descriptive statistics) of the data, dispersion analysis, and for the graphical representation of the results. For the statistical evaluation of the most polluted stations, 50th (median) and 90th percentile have been considered for comparison with the EQS as these statistics are most appropriate to represent higher concentrations and to avoid bias caused by values lower than LOQs.

\section{Results and discussion}

\section{General data comparability}

For the six trace elements analyzed (As, $\mathrm{Cd}, \mathrm{Cr}, \mathrm{Hg}, \mathrm{Ni}$, $\mathrm{Pb}$ ) in the 12 sampling stations monitored, a total of $\mathrm{n}$. 13,753 analyses, between total and dissolved form, have been performed. All these validated data were filtered and selected for the purposes of this paper. Hence, the six most significant monitoring stations, based on the principal tributary, were selected for the statistical assessment and temporal trend analysis. Single station data, during the 15 years considered, vary from n. 654 to n. 799 analytical results, while for each station, data collected for every metal are between 109 and 134 . The yearly monitoring plan included analyses of the dissolved form for a maximum of 12 samples for each sampling station (Tab. SM1).

For the determination of metals, the laboratory of ARPAV has improved analytical tools with highly specialized instrumentation for routine controls and monitoring of environmental samples. The laboratory used mainly the ICP-MS technique that, during the years, was improved with respect to interference removal using the reaction cell instead of empiric equations. To provide higher sensitivity in determining $\mathrm{Hg}$, the CV-AAS technique used during the first period was replaced by the AFS. In the meantime, in the 15 years considered, analytical procedures have been optimized in order to adjust the LOQs for compliance with the regulations in force (Table 1).

First of all, on the available raw data, a filtering assessment has been performed by analyzing them with respect to the LOQ value, which simply indicates the presence/absence of a substance. The change of LOQs in the 15 years according to analytical improvement makes it difficult to obtain a homogeneous comparison of the data throughout the whole period considered. However, considerations are possible for wide periods for most of the trace elements. The more significant results obtained above LOQs mainly refer to the As and Ni parameter and, to a lesser extent, to $\mathrm{Cr}$.

A preliminary assessment of the percentage of data above or below the LOQs allows understanding how the analytical technique adopted affects or does not affect this evaluation (Table 2). For elaborations and comparisons, all values lower than LOQ have been treated according to the guidelines of European regulations that set the numerical data as $1 / 2$ LOQ. This approach (i.e., each minimum values represented in Tab. SM1 is never equal to zero) leads to a conservative estimation of the contamination of the water bodies. For dissolved $\mathrm{Pb}$, $\mathrm{Hg}$, and $\mathrm{Cd}$, very few data are positive and detected above the LOQ so it is not possible to obtain a clear trend assessment over the 15 years (Table 2). Hence, only $\mathrm{As}, \mathrm{Ni}$, and $\mathrm{Cr}$ are graphically represented in the paper because they are the trace elements that show a significant trend. However, to complete the data set, the graphical elaboration of $\mathrm{Cd}$ and $\mathrm{Pb}$ are provided with the Supplementary Material (SM), while for $\mathrm{Hg}$, it was not considered of interest for the few data.

\section{Evaluation of temporal trends of trace elements}

The parameter As was detected over the LOQ during almost all the periods considered in all the six sampling stations. It is less detectable in sampling station \#143, while in the other monitoring stations (\#492, \#489, $\# 490$, \#179, \#504), it is present with a wide spread of data. The average monthly concentrations calculated for the dissolved As are graphically interpreted in Fig. 2 in order to highlight the time variation of concentration of the parameter in question. No large dispersion of data is documented for each single sampling station. Indeed, temporal trends of the As concentration are basically constant and thus the presence of periodicity is detected. Fluctuations are however observed with concentration 
Table 2 Percentages of concentrations below the LOQ for the selected sampling station during the period from 2000 to 2015

\begin{tabular}{|c|c|c|c|c|c|c|c|}
\hline \multirow[t]{2}{*}{ Parameter } & \multirow{2}{*}{$\begin{array}{l}\% \text { values }<\text { LOQ and } \\
\text { referred period }\end{array}$} & \multicolumn{6}{|c|}{ Sampling station } \\
\hline & & $\begin{array}{l}\# 143 \\
\text { Zero }\end{array}$ & $\begin{array}{l}\# 492 \\
\text { Cuori }\end{array}$ & $\begin{array}{l}\text { \#489 } \\
\text { Marzenego }\end{array}$ & $\begin{array}{l}\text { \#490 } \\
\text { Lusore }\end{array}$ & $\begin{array}{l}\# 179 \\
\text { Fiumazzo }\end{array}$ & $\begin{array}{l}\# 504 \\
\text { Novissimo }\end{array}$ \\
\hline \multirow[t]{2}{*}{ Arsenic (As) } & $\begin{array}{l}\%<\text { LOQ } 2.0 \\
(2001)\end{array}$ & $14 \%$ & $0 \%$ & $0 \%$ & $17 \%$ & $0 \%$ & - \\
\hline & $\begin{array}{l}\%<\text { LOQ } 1.0 \\
(2002-2015)\end{array}$ & $6 \%$ & $2 \%$ & $2 \%$ & $0 \%$ & $2 \%$ & $1 \%$ \\
\hline \multirow[t]{4}{*}{ Cadmium (Cd) } & $\begin{array}{l}\%<\text { LOQ } 1.0 \\
(2000-2001)\end{array}$ & $100 \%$ & $100 \%$ & $100 \%$ & $100 \%$ & $100 \%$ & - \\
\hline & $\begin{array}{l}\%<\text { LOQ } 0.5 \\
(2002-2006)\end{array}$ & $100 \%$ & $100 \%$ & $100 \%$ & $100 \%$ & $100 \%$ & $100 \%$ \\
\hline & $\begin{array}{l}\%<\text { LOQ } 0.2 \\
(2007-2011)\end{array}$ & $100 \%$ & $100 \%$ & $100 \%$ & $100 \%$ & $100 \%$ & $100 \%$ \\
\hline & $\begin{array}{l}\%<\text { LOQ } 0.1 \\
(2012-2015)\end{array}$ & $100 \%$ & $91 \%$ & $87 \%$ & $85 \%$ & $85 \%$ & $83 \%$ \\
\hline \multirow[t]{3}{*}{ Chromium (Cr) } & $\begin{array}{l}\%<\text { LOQ } 10 \\
(2000-2001)\end{array}$ & $100 \%$ & $100 \%$ & $100 \%$ & $100 \%$ & $100 \%$ & - \\
\hline & $\begin{array}{l}\%<\text { LOQ } 1.0 \\
(2002-2012)\end{array}$ & $91 \%$ & $69 \%$ & $86 \%$ & $84 \%$ & $82 \%$ & $84 \%$ \\
\hline & $\begin{array}{l}\%<\text { LOQ } 0.5 \\
(2013-2015)\end{array}$ & $97 \%$ & $46 \%$ & $100 \%$ & $100 \%$ & $100 \%$ & $97 \%$ \\
\hline \multirow[t]{2}{*}{ Lead $(\mathrm{Pb})$} & $\begin{array}{l}\%<\text { LOQ } 5.0 \\
(2000-2001)\end{array}$ & $92 \%$ & $100 \%$ & $100 \%$ & $100 \%$ & $90 \%$ & - \\
\hline & $\begin{array}{l}\%<\text { LOQ } 0.5 \\
(2002-2015)\end{array}$ & $100 \%$ & $96 \%$ & $94 \%$ & $94 \%$ & $98 \%$ & $100 \%$ \\
\hline \multirow[t]{3}{*}{ Mercury (Hg) } & $\begin{array}{l}\%<\text { LOQ } 1.0 \\
(2000-2006)\end{array}$ & $100 \%$ & $100 \%$ & $100 \%$ & $100 \%$ & $97 \%$ & $98 \%$ \\
\hline & $\begin{array}{l}\%<\text { LOQ } 0.2 \\
(2007-2012)\end{array}$ & $100 \%$ & $100 \%$ & $100 \%$ & $100 \%$ & $100 \%$ & $100 \%$ \\
\hline & $\begin{array}{l}\%<\text { LOQ } 0.010 \\
(2012-2015)\end{array}$ & $100 \%$ & $100 \%$ & $100 \%$ & $100 \%$ & $100 \%$ & $100 \%$ \\
\hline \multirow[t]{2}{*}{ Nickel (Ni) } & $\begin{array}{l}\%<\text { LOQ } 5.0 \\
(2000-2001)\end{array}$ & $92 \%$ & $100 \%$ & $100 \%$ & $100 \%$ & $90 \%$ & - \\
\hline & $\begin{array}{l}\%<\text { LOQ } 1.0 \\
(2002-2015)\end{array}$ & $51 \%$ & $3 \%$ & $67 \%$ & $16 \%$ & $51 \%$ & $74 \%$ \\
\hline
\end{tabular}

peaks in 2003, 2007, and 2012 and in 2015. For instance, in 2012, a peak of $48.5 \mu \mathrm{g} / \mathrm{L}$ in Fiumazzo, $27.9 \mu \mathrm{g} / \mathrm{L}$ in Lusore, and $17.6 \mu \mathrm{g} / \mathrm{L}$ in MarzenegoOsellino, was recorded. In the year 2015, the concentration rates recorded an increase in all the mouth stations. Especially, Lusore (North Lagoon) shows a peak concentration of $31.7 \mu \mathrm{g} / \mathrm{L}$, Cuori (South Lagoon) of $15.6 \mu \mathrm{g} / \mathrm{L}$, and Marzenego-Osellino (North Lagoon) of $13.1 \mu \mathrm{g} / \mathrm{L}$. During the 15 years of study, all the representative curves of the six river mouth sampling stations have a substantially similar trend (while maintaining value variations). Lusore (\#490) and Fiumazzo (\#179) have positive concentrations very high in relation to other river mouth sampling stations analyzed, with data sequences that on average exceed the value of
$10.0 \mu \mathrm{g} / \mathrm{L}$. This is confirmed also from dispersion analysis with variance of 30 and 25.9 for Fiumazzo and Lusore, respectively, in comparison with values of 0.79 and 1.29 for Novissimo and Zero, respectively. Therefore, stations \#179 and \#490 are the most critical areas concerning the level of pollution. Data in Table 2 are comparable before and after improvement of the analytical technique (i.e., $2.0 \mu \mathrm{g} / \mathrm{L}$ in year 2001 and $1.0 \mu \mathrm{g} / \mathrm{L}$ from year 2002 to 2015 ) showing that the method in use was suitable to detect positive values even before the update of the instrumentation.

Concerning the parameter $\mathrm{Ni}$, there is no particular difficulty in comparing data during the 15 years of study, apart from the first year. The improvement of the techniques was reached already in 2002 with 
TREND OF DISSOLVED ARSENIC [ $\mu \mathrm{g} / \mathrm{L}]$ FOR THE SELECTED MONITORING STATIONS

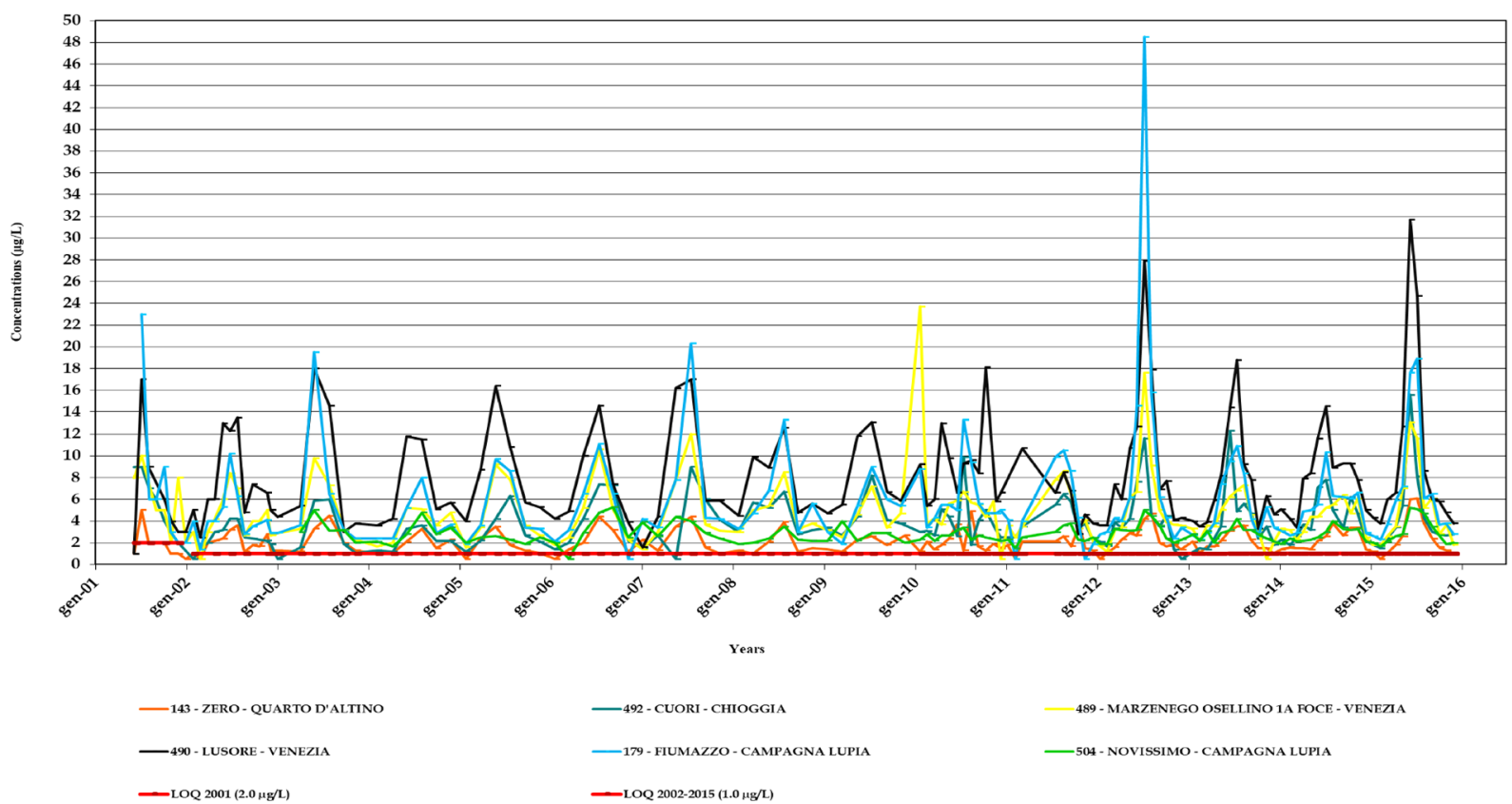

Fig. 2 Temporal trend of dissolved As over the years 2001-2015 (monthly averages) compared with the improvement of LOQs values in different time periods

adequate LOQ from 5.0 to $1.0 \mu \mathrm{g} / \mathrm{L}$, demonstrable by the lower percent of values < LOQ after 2002 (Table 2). All the six river mouth sampling stations have several data above LOQ during the years 2002-2015, while in the period 2000-2001, not one of them was higher than $5.0 \mu \mathrm{g} / \mathrm{L}$. This implies that the improvement of the technique has made a positive contribution to the environmental monitoring. The average monthly concentrations over the considered years calculated for the dissolved $\mathrm{Ni}$ is represented in Fig. 3. On average, the maximum values in the six sampling stations in the Lagoon watershed present values mainly in the range of $4.0-6.0 \mu \mathrm{g} / \mathrm{L}$ with some values of 7.0, 8.0, and $9.0 \mu \mathrm{g} / \mathrm{L}$. Exceptions are for Lusore (\#490) and Cuori (\#492) with several spike values, especially for Cuori. Indeed, the station \#492 has a very high data dispersion confirmed by concentration peaks circumscribed over the years $2003(32.0 \mu \mathrm{g} / \mathrm{L}), 2009(17.8 \mu \mathrm{g} / \mathrm{L}), 2012$ $(32.2 \mu \mathrm{g} / \mathrm{L})$, and $2013(24.5 \mu \mathrm{g} / \mathrm{L})$. Its calculated variance is 25.1 , therefore defined as the most polluted station. As comparison, the variance of the less polluted sampling station from $\mathrm{Ni}$ (\#504, Novissimo) is 0.27 . Also, the station \#490 (variance 1.09) can be indicated at risk with moderate concentration peaks in the years 2004 (4.2 $\mu \mathrm{g} / \mathrm{L} ; 4.8 \mu \mathrm{g} / \mathrm{L}), 2006$ (7.4 $\mu \mathrm{g} / \mathrm{L}), 2008$
(4.0 $\mu \mathrm{g} / \mathrm{L}), 2010(3.8 \mu \mathrm{g} / \mathrm{L}), 2012(3.2 \mu \mathrm{g} / \mathrm{L})$, and $2014(5.0 \mu \mathrm{g} / \mathrm{L})$.

The LOQ for Cd was improved several times during the 15 years considered. In particular, as shown in Table 1 , from $1.0 \mu \mathrm{g} / \mathrm{L}$, it was improved to $0.5 \mu \mathrm{g} / \mathrm{L}$, then $0.2 \mu \mathrm{g} / \mathrm{L}$ and finally in 2012 at $0.1 \mu \mathrm{g} / \mathrm{L}$ that is the value currently achieved. In this case, the achievement of satisfactory LOQ was essential to demonstrate some positive results. While for \#143 Zero, all values were below the LOQ, in these last 3 years assessed the few positive data were all in the range between 0.1 and $0.4 \mu \mathrm{g} / \mathrm{L}$ for the other five stations. The maximum of $0.4 \mu \mathrm{g} / \mathrm{L}$ was detected in \#489 Marzenego in 2012 and \#179 Fiumazzo in 2014. The graphical representation of the temporal trend for the years between 2012 and 2015 is in the Supplementary Material (Fig. SM1).

For Cr, the LOQ was improved of one order of magnitude already in 2002 and this improvement of the analytical procedure was essential to provide more reliable data (Fig. 4). The decrease of the LOQ in $\mu \mathrm{g} / \mathrm{L}$ in different periods from $10.0 \mu \mathrm{g} / \mathrm{L}$ (years 2000-2001) to $1.0 \mu \mathrm{g} / \mathrm{L}$ (years $2002-2012$ ) and to $0.5 \mu \mathrm{g} / \mathrm{L}$ (years 2013-2015) has been obtained by refining the ICP-MS procedure. In general, $\mathrm{Cr}$ does not present high levels of excess above the LOQ. If for most of the sampling 
TREND OF DISSOLVED NICKEL $[\mu \mathrm{g} / L$ ] FOR THE SELECTED MONITORING STATIONS

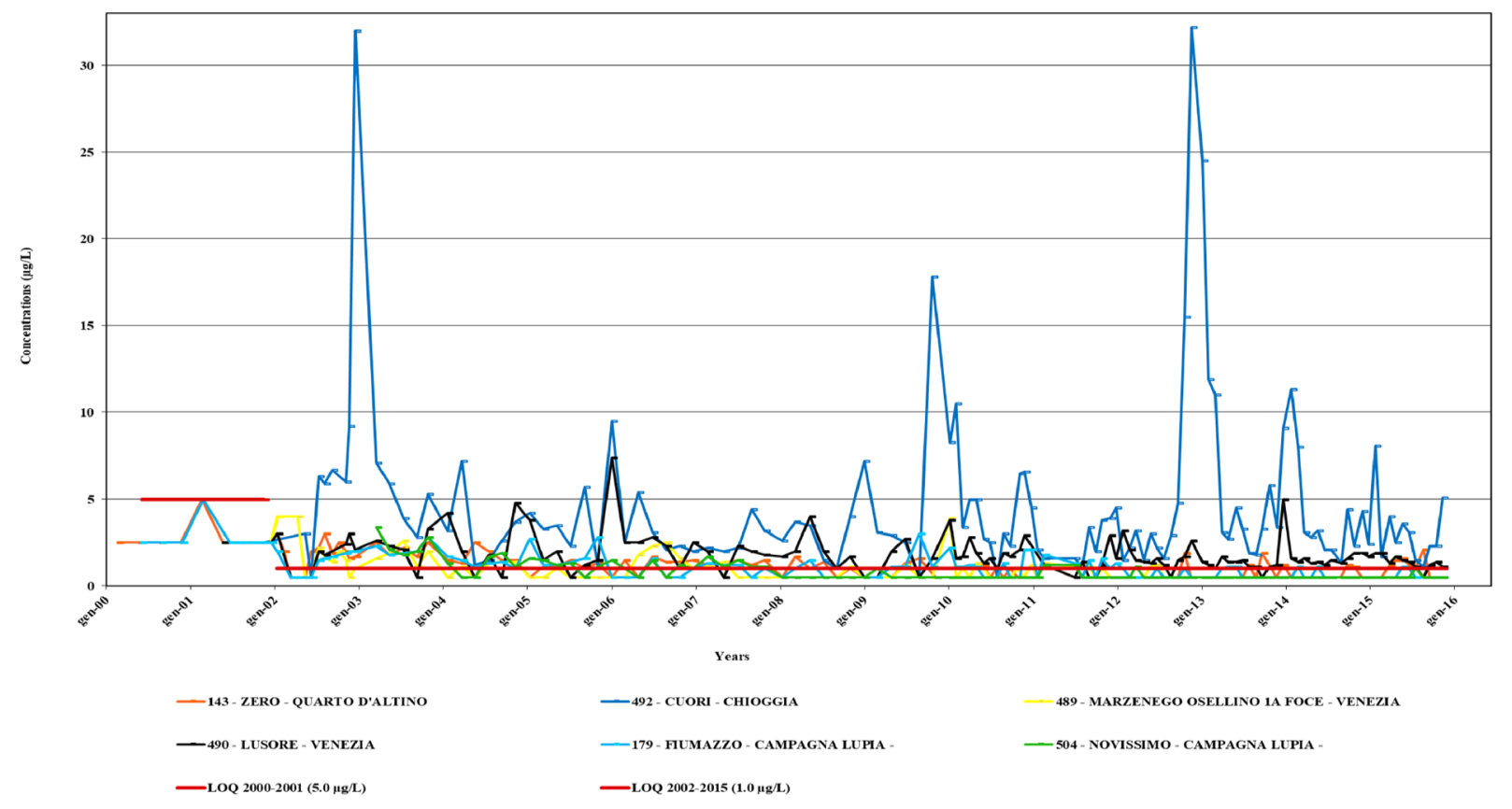

Fig. 3 Temporal trend of dissolved Ni over the years 2000-2015 (monthly averages) compared with the improvement of LOQs values in different time periods

TREND OF DISSOLVED CROMIUM [ $\mu \mathrm{g} / \mathrm{L}]$ FOR THE SELECTED MONITORING STATIONS FROM 2002 TO 2015
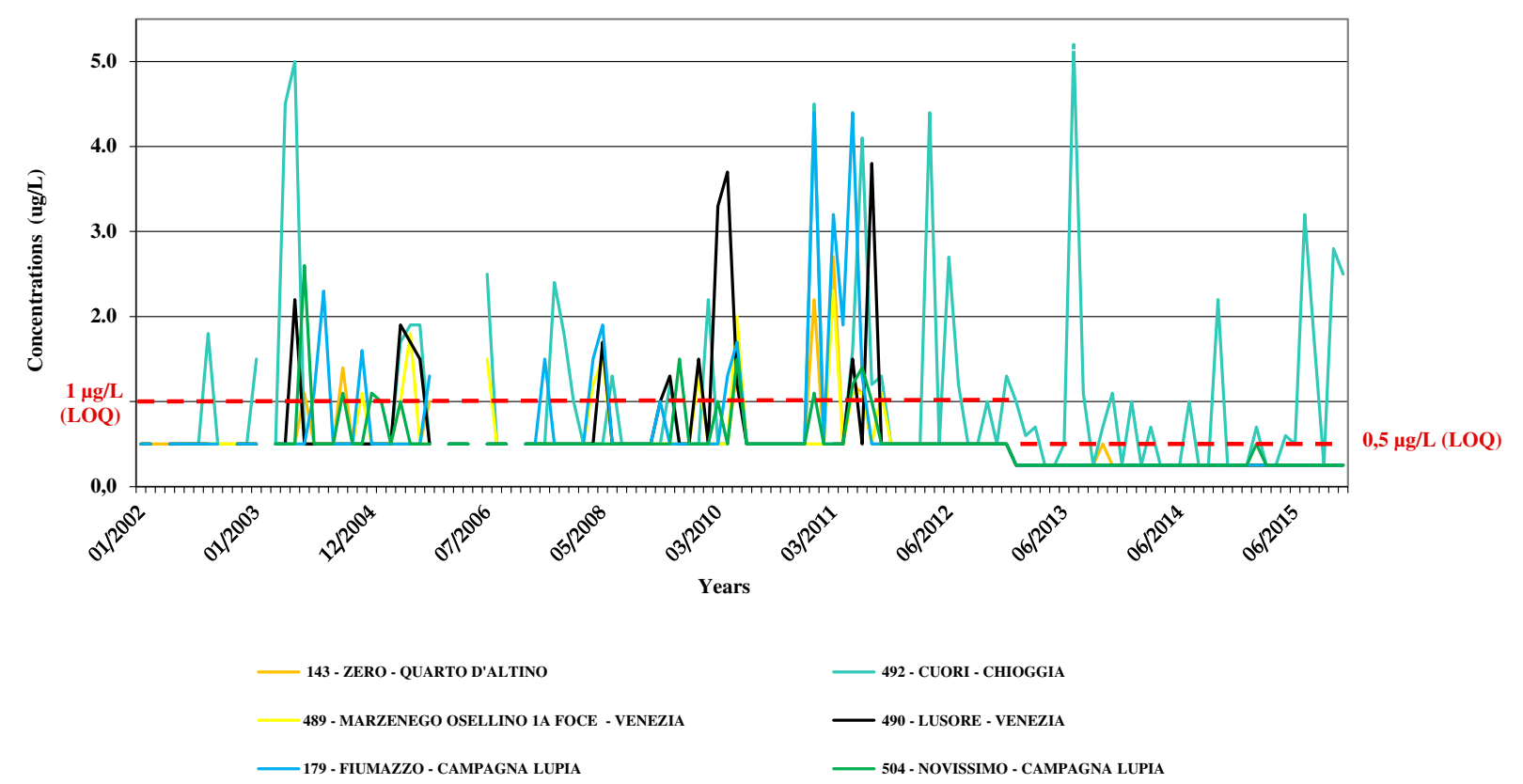

179 - FIUMAZZO - CAMPAGNA LUPIA

504 - NOVISSIMO - CAMPAGNA LUPIA

Fig. 4 Temporal trend of dissolved Cr over the years 2002-2015 (monthly averages) compared with the improvement of LOQs values in different time periods 
points some positive data were obtained during the period 2002-2012 (i.e., values > LOQ), it is clear that after 2013 the environmental situation was improved for most of the considered sampling stations. In five of the sampling stations, values are in the range of 1.0-4.4. Different is the situation of sampling station Cuori channel (\#492) where several positive data are still detectable in 2015 and with peaks of $5.0 \mu \mathrm{g} / \mathrm{L}$ and $5.2 \mu \mathrm{g} / \mathrm{L}$, in 2003 and 2013 respectively. This suggests that $\mathrm{Cr}$ is still a critic parameter to monitor for this water body.

The parameter $\mathrm{Hg}$ was the most challenging because the analytical instrumentation has been adapted to the legislation only during the recent years (2012-2015). The laboratory applied different analytical techniques: from atomic absorption with method of cold vapor (CVAAS) to a subsequent use of the ICP-MS technique until the instrumentation currently in use since 2012 based on the AFS technique. All the values in the dissolved forms are lower than LOQ, decreased over the time from 1.0 to $0.2 \mu \mathrm{g} / \mathrm{L}$ up to $0.010 \mu \mathrm{g} / \mathrm{L}$, apart two single cases were $\mathrm{Hg}$ concentration was detected at $1 \mu \mathrm{g} / \mathrm{L}$ in 2004 in two different sampling stations.

The last parameter considered in the study is $\mathrm{Pb}$, for which there are no substantial difficulties in comparison. Most of the data are lower than LOQ, even after a substantial improvement of the analytical procedure of one order of magnitude (from $5.0 \mu \mathrm{g} / \mathrm{L}$ during the period $2000-2001$ to $0.5 \mu \mathrm{g} / \mathrm{L}$ during the period
2002-2015). Very few data are higher than LOQ; hence, a proper comparison is difficult to obtain (Fig. SM2 in the Supplementary Material).

Comparison between water flow and concentration

This research has also investigated how much the seasonal water flow affected the concentration in order to assess whether lean/flood periods (i.e., values of average monthly flow lower or higher than the annual average flow) correspond to high or low concentrations of pollutants. The quantitative flow data were provided by the Ministry of Infrastructure and Transport-Interregional Department for OOPP Triveneto (formerly VWA, Venice Water Authority) and Consorzio Venezia Nuova (CVN, VWA's unique concessionary). VWA has controlled the quality of water discharges in the lagoon since the second half of the 1980s, providing an updated the picture of the lagoon state through the results of regular monitoring projects (Solidoro et al. 2004; Carrer et al. 2005; Pastres and Solidoro 2012). The general picture of the contribution of the basin in terms of loads, only considering the dissolved form, is represented in Fig. 5.

From the figure, it is clear that the major contribution in terms of loads is due to As and Ni. Hence, some specific situations referred to the dissolved As and dissolved Ni were assessed and are reported here as

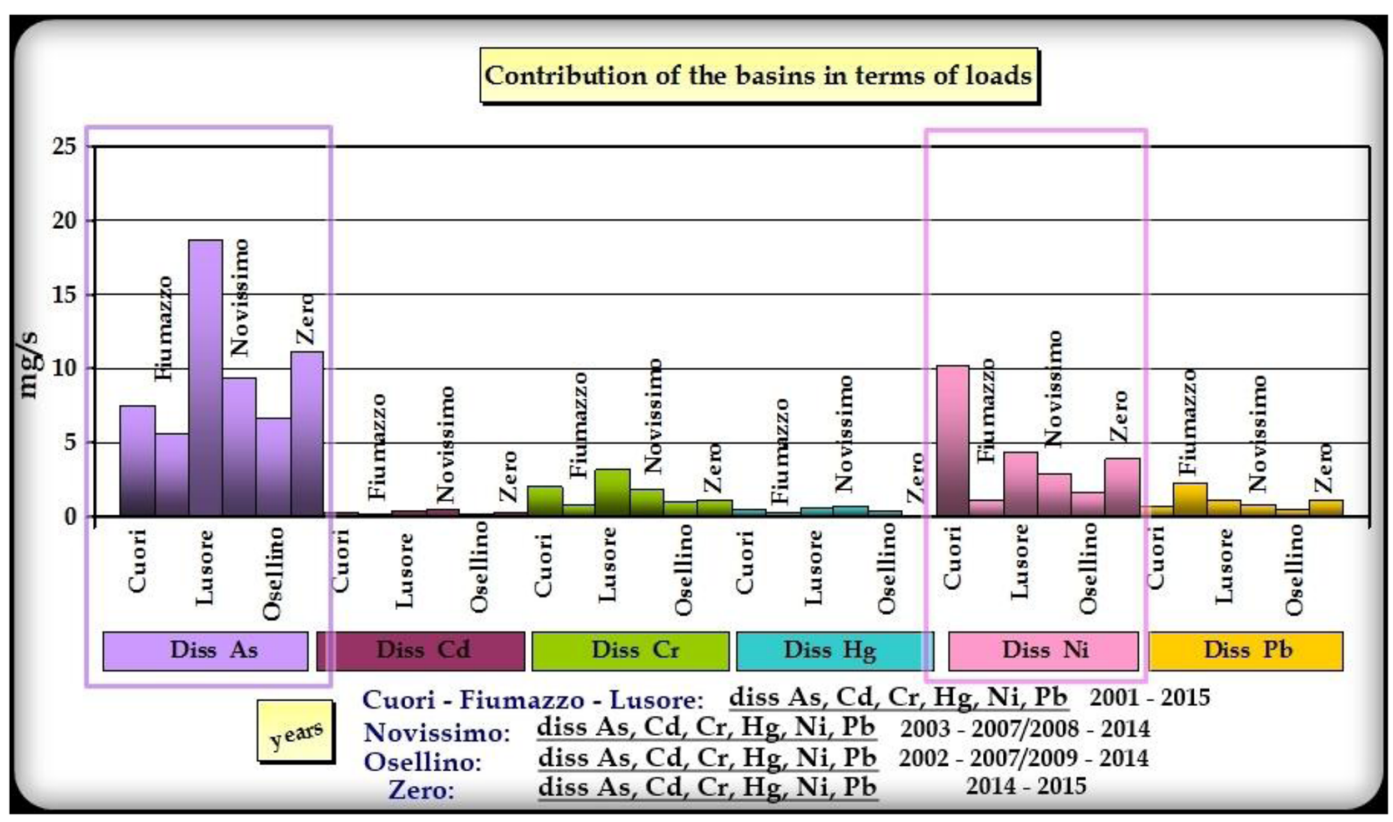

Fig. 5 Contribution of the basin in terms of loads considering the dissolved form of the trace elements 
example. In particular, the stations showing high monthly peaks of concentration have been chosen (Lusore and Fiumazzo channels for dissolved As; Cuori channel for dissolved $\mathrm{Ni}$ ), according to trends represented in Figs. 2 and 3. During flood events, in addition to discharges, there is an increase in flow rate and an increase in runoff. On the contrary, during lean events, there are only discharges. From the evaluation of the concentration analyzed in the 2000-2015 period compared to the flow, it emerges that there is not always a dilution effect during flood period. There are cases in which a higher flow corresponds to higher concentration, and thus greater load. For a general outlook on the measured water flow in the selected water bodies, the mean and median values calculated on a daily basis in the whole period 2000-2015 are reported in Tab. SM1.

For instance, as example for the dissolved As, in the sampling station Lusore (\#490), in February 2014 a monthly flow of $5.5 \mathrm{~m}^{3} / \mathrm{s}$, higher than the average annual flow of $5.1 \mathrm{~m}^{3} / \mathrm{s}$, corresponds to high concentration of $4.2 \mu \mathrm{g} / \mathrm{L}$, thus a load of $23.1 \mathrm{mg} / \mathrm{s}$. According to the data, loads derived during lean times were much lower (e.g., January 2014, $11.2 \mathrm{mg} / \mathrm{s}$; March 2014: $1.7 \mathrm{mg} / \mathrm{s}$; December 2014: $15.0 \mathrm{mg} / \mathrm{s}$ ). In the same water body, another peak of average monthly flow of $14.6 \mathrm{~m}^{3} / \mathrm{s}$ was recorded in November 2014 . This period corresponded at a high dissolved As concentration $(7.8 \mu \mathrm{g} / \mathrm{L})$ and consequently at a load of $113.9 \mathrm{mg} / \mathrm{s}$. Concerning the sampling station in Fiumazzo (\#179), always in February 2014, an average flow equal to $4.8 \mathrm{~m}^{3} / \mathrm{s}$ was recorded, evidently higher than the average annual flow of $1.4 \mathrm{~m}^{3} / \mathrm{s}$. However, this flood period does not correspond to a particularly high concentration $(2.7 \mu \mathrm{g} / \mathrm{L})$ compared with higher concentrations corresponding to lean periods (January 2014, $3.1 \mu \mathrm{g} / \mathrm{L}$; March 2014, $2.9 \mu \mathrm{g} / \mathrm{L}$; April 2014, $4.9 \mu \mathrm{g} / \mathrm{L}$;

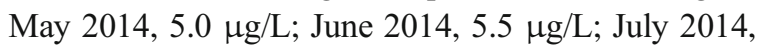
$10.3 \mu \mathrm{g} / \mathrm{L}$; August 2014, $6.3 \mu \mathrm{g} / \mathrm{L}$; September 2014, $6.2 \mu \mathrm{g} / \mathrm{L}$; October 2014, $6.1 \mu \mathrm{g} / \mathrm{L}$; December 2014, $2.9 \mu \mathrm{g} / \mathrm{L}$ ). This leads to the conclusion that lean and flood periods do not correspond always to high and low concentrations of pollutants.

The same conclusion for As can be confirmed also for dissolved Ni. The years taken as example for $\mathrm{Ni}$ are 2002 and 2010. Considering the sampling station Cuori channel (\#492), four characteristic situations are outlined for the year 2002. In June 2002, there is evidence of lean season (average monthly flow equal to $0.9 \mathrm{~m}^{3} / \mathrm{s}$ ) that corresponds to a low concentration recorded $(3.0 \mu \mathrm{g} / \mathrm{L})$. In the same year, on months of July, August, and December, for low average monthly flow of $0.7 \mathrm{~m}^{3} / \mathrm{s}, 0.9 \mathrm{~m}^{3} / \mathrm{s}$, and $2.3 \mathrm{~m}^{3} / \mathrm{s}$ corresponded low concentrations of $0.5 \mu \mathrm{g} / \mathrm{L}, 6.3 \mu \mathrm{g} / \mathrm{L}$, and $9.2 \mu \mathrm{g} / \mathrm{L}$, respectively. Finally, again in August and in November 2002, there is evidence of flood season (average monthly flows equal to $9.5 \mathrm{~m}^{3} / \mathrm{s}$ and $14.3 \mathrm{~m}^{3} / \mathrm{s}$ compared to average annual flow corresponding to $\left.4.3 \mathrm{~m}^{3} / \mathrm{s}\right)$, which corresponds with high concentrations $(5.9 \mu \mathrm{g} / \mathrm{L}$ and $6.0 \mu \mathrm{g} / \mathrm{L})$ and at high load peaks $(56.05 \mathrm{mg} / \mathrm{s}$ and $85.8 \mathrm{mg} / \mathrm{s}$ ). In 2010, similar situations for lean and flood periods are detectable. Starting from the lean season, there is evidence of a low average monthly flow $\left(0.5 \mathrm{~m}^{3} / \mathrm{s}\right.$ in January and $5.3 \mathrm{~m}^{3} / \mathrm{s}$ in December) which corresponds with a high concentration $(8.3 \mu \mathrm{g} / \mathrm{L}$ in January and $6.6 \mu \mathrm{g} / \mathrm{L}$ in December) and alternatively for the 2 months analyzed to a low and a high load $(4.2 \mathrm{mg} / \mathrm{s}$ in January and $34.9 \mathrm{mg} / \mathrm{s}$ in December).

On the contrary, there is also evidence of a low average monthly flow $\left(0.3 \mathrm{~m}^{3} / \mathrm{s}\right.$ in August and $0.6 \mathrm{~m}^{3} / \mathrm{s}$ in October), which corresponds to a low concentration $(0.5 \mu \mathrm{g} / \mathrm{L}$ in August and $2.3 \mu \mathrm{g} / \mathrm{L}$ in October). Like for flood periods, two other situations are outlined. Three peaks of average monthly flow are detectable in February $\left(17.1 \mathrm{~m}^{3} / \mathrm{s}\right)$, May $\left(9.3 \mathrm{~m}^{3} / \mathrm{s}\right)$, and November $\left(18.8 \mathrm{~m}^{3} / \mathrm{s}\right)$ which correspond to high concentrations $(10.5 \mu \mathrm{g} / \mathrm{L}$ in February, $5.0 \mu \mathrm{g} / \mathrm{L}$ in May and $6.5 \mu \mathrm{g} / \mathrm{L}$ in November) and to high loads $(179.6 \mathrm{mg} / \mathrm{s} ; 46.5 \mathrm{mg} / \mathrm{s}$ and $122.2 \mathrm{mg} / \mathrm{s}$, respectively, for months previously reported). Finally, in June there is a peak of average monthly flow $\left(24.2 \mathrm{~m}^{3} / \mathrm{s}\right)$, which however corresponds to a low concentration $(2.7 \mu \mathrm{g} / \mathrm{L})$ although with a high load $(65.34 \mathrm{mg} / \mathrm{s})$.

This comparison was performed as a preliminary assessment, since the estimation of the load of each pollutant needs a more deep investigation considering mainly the total concentration of the trace elements instead of the dissolved form. Moreover, the elaboration represented in Fig. 5 takes into account the values lower LOQs as positive as $1 / 2$ of the same LOQ values, as already stated previously, leading to a conservative approach in terms of loads. Additional estimations are needed and will be material for a further study.

Cumulated frequency distribution and comparison with EQS

Data presented in the previous paragraphs are compared with EU and local EQS by means of cumulative 
frequency curves, as described above. This application can identify stations where the priority substances under analysis may pose a significant concern to freshwater ecosystems. For comparison, EQSs in force for surface waters and the limit values for discharges are compared with the relative cumulated frequency of the contaminants sampled in the river inlets (stations shown in Fig. 1). Situations of concern are highlighted with concentration values above standard values (EQSs and discharge limit values).

In order to facilitate the interpretation of the data analysis for the investigated trace elements, the stations have been divided into three different subgroups, depending on the geographical location: (1) North Lagoon: Zero Quarto d'Altino (\#143), MarzenegoOsellino (\#489), Lusore (\#490); (2) Central Lagoon: Fiumazzo (\#179), Novissimo (\#504); and (3) South Lagoon: Cuori (\#492). The choice to represent the cumulative frequencies analyzing only dissolved concentrations is dictated by the fact that the regulatory EQSs refer to dissolved concentrations, i.e., the dissolved phase of a water sample obtained after filtration with a $0.45-\mu \mathrm{m}$ filter or other equivalent pre-treatment process. Since the sampling stations are not in proximity of a discharge, comparisons shall be made mostly with EQS from Italian Decree 23/04/1998 and the WFD. Results are shown for $\mathrm{As}, \mathrm{Ni}, \mathrm{Cr}$, and $\mathrm{Pb}$ as for $\mathrm{Hg}$ and $\mathrm{Cd}$ only a few measurements are detected over the LOQ.

The most important industrial sources of As insisting in the area are the foundries and glass factories (Giusti and Zhang 2002). Furthermore, another source of As comes from agriculture as As was used as an ingredient in pesticides (Zatta et al. 1992). As is not included in the WFD as a priority pollutant, but it is taken into consideration in local legislation, as shown in Table 1. Dissolved As shows significant overruns with respect to the special legislation for the Venice Lagoon (Italian Decree $30 / 07 / 1999$ ) in terms of discharge limit values mostly in the Lusore station \#490 (more than the $20 \%$ of the samples are above the EQS of $10 \mu \mathrm{g} / \mathrm{L}$ ), as it can be observed in Fig. 6. Considering the other monitoring stations, they present 88 to $100 \%$ of the values below $10 \mu \mathrm{g} / \mathrm{L}$ (concentration limit value at the discharge fixed for the Venice Lagoon regulation, Italian Decree 30/07/ 1999). With respect to the limit value posed by Italian Decree 23/04/1998, from 91 to $100 \%$ of the sampled values across the six sampling stations present a concentration above the limit of $0.9 \mu \mathrm{g} / \mathrm{L}$.

$\mathrm{Cr}$ is emitted as industrial discharge; it is used in the tanning industries located in the Vicenza area, a few tens

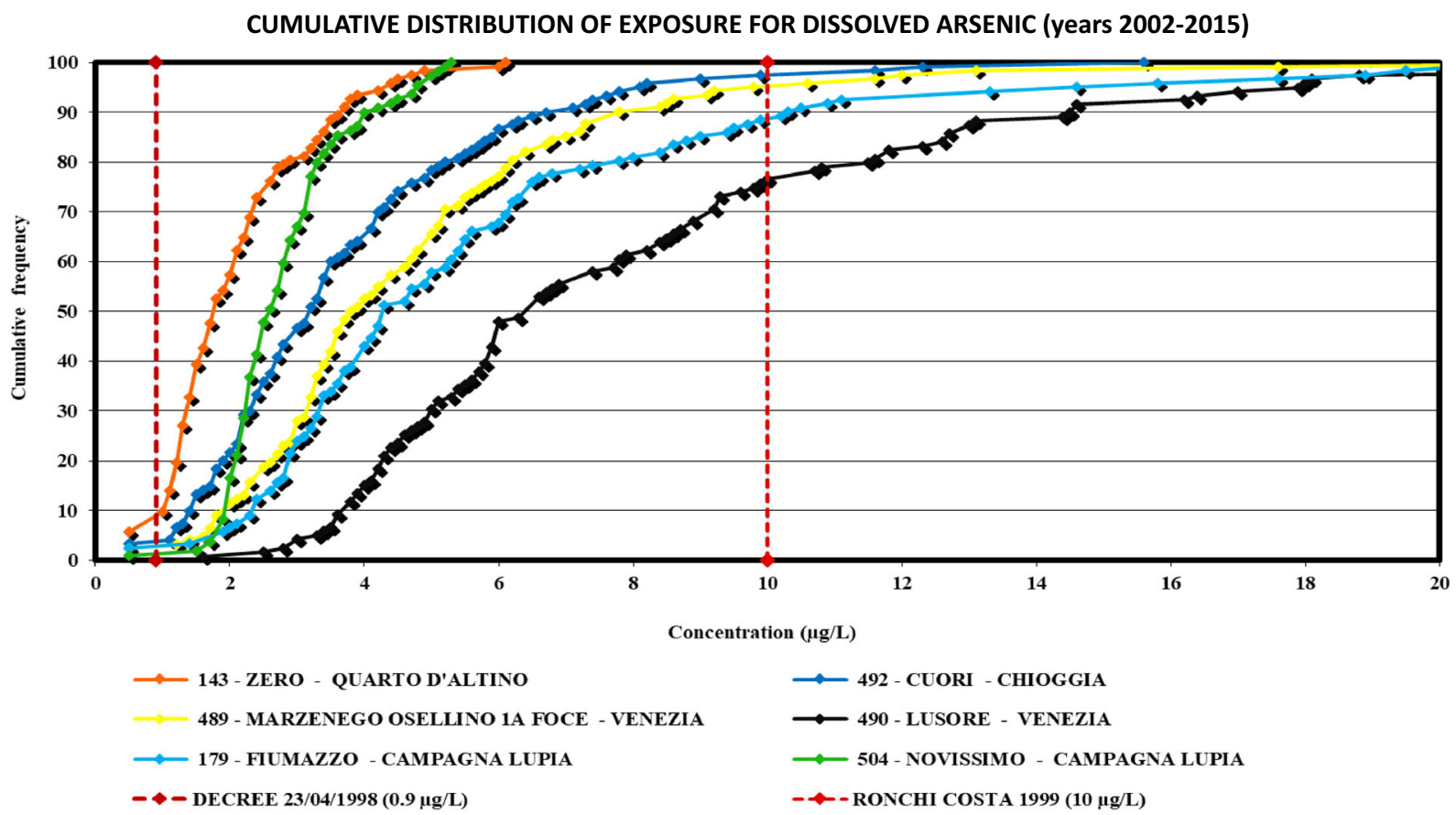

Fig. 6 Cumulative distribution of exposure (monthly averages from 2002 to 2015) for dissolved As versus local EQS (Decrees 23/04/1998 and 30/07/1999) 
of kilometers from Venice, moreover in numerous small and medium-sized industries in the Veneto Region and in the industrial area of Porto Marghera (Zatta et al. 1992). Cr is not considered as a priority or hazardous pollutant in the WFD, but it is listed in Italian legislation (Table 1), like As. Although monitored values are mostly below the EQS (Fig. SM3), the curve that requires greater attention is represented by the Cuori \#492 channel station. In particular, this station differs significantly from the other stations in each point of the curve and reaches the 90th percentile between the values of 2.1 and $2.4 \mu \mathrm{g} / \mathrm{L}$. These values are almost double in relation to the other five stations where $90 \%$ of values are comprised between values of 1.1 and $1.4 \mu \mathrm{g} / \mathrm{L}$.

For the $\mathrm{Ni}$, the 70 up to the $90 \%$ of the values are below the EU EQS as shown in Fig. 7. Most polluted stations are identified in Cuori and Lusore channels, reaching the 50th percentile respectively at 3.0 and $1.5 \mu \mathrm{g} / \mathrm{L}$. Particularly, at the 90th percentile, Cuori channel is even more distanced from the other curves. In fact, it reaches the $90 \%$ of the detections in correspondence of the EU EQS of $8.6 \mu \mathrm{g} / \mathrm{L}$ against a value equivalent to $3.0 \mu \mathrm{g} / \mathrm{L}$ for Lusore channel. Instead, the remaining curves of empirical distribution (Zero and Marzenego-Osellino, Fiumazzo Drain, and Novissimo) reach the 90th percentile in the range of values between 2.0 and $1.0 \mu \mathrm{g} / \mathrm{L}$. Cuori sampling station, with very high concentrations but well distributed throughout the area of the cumulative representation, is the most critical one. Concerning $\mathrm{Ni}$, if comparison is made with the lowest local EQS (Table 1), the situation does not represent a good environmental status and the case study could undergo a risk analysis in a further step (Fig. 7).

In order to complete the cognitive framework of all dissolved metals and to obtain a preliminary assessment of the monitoring activities by comparison with EQS, a last consideration has to be made about the $\mathrm{Pb}$ parameter (Fig. SM4). Concerning dissolved $\mathrm{Pb}$, excluding the highest concentration peaks, no curve differs significantly from the others. About $95 \%$ of the data is noted below the LOQ of $0.5 \mu \mathrm{g} / \mathrm{L}$. Overruns were observed in few samplings (1-2\%) at Cuori channel, whose curves extend to $\approx 2.6 \mu \mathrm{g} / \mathrm{L}$ in the cumulative area; Marzenego river, around $3.5 \mu \mathrm{g} / \mathrm{L}$ and Lusore channel above the value of $7.0 \mu \mathrm{g} / \mathrm{L}$. The Lusore channel station goes beyond the target $(7.2 \mu \mathrm{g} / \mathrm{L})$ also according to Directive 2008/105/EC.

From the comparison of the dissolved metals concentrations with the identified EQSs in force, it was possible to identify the river mouth sampling stations

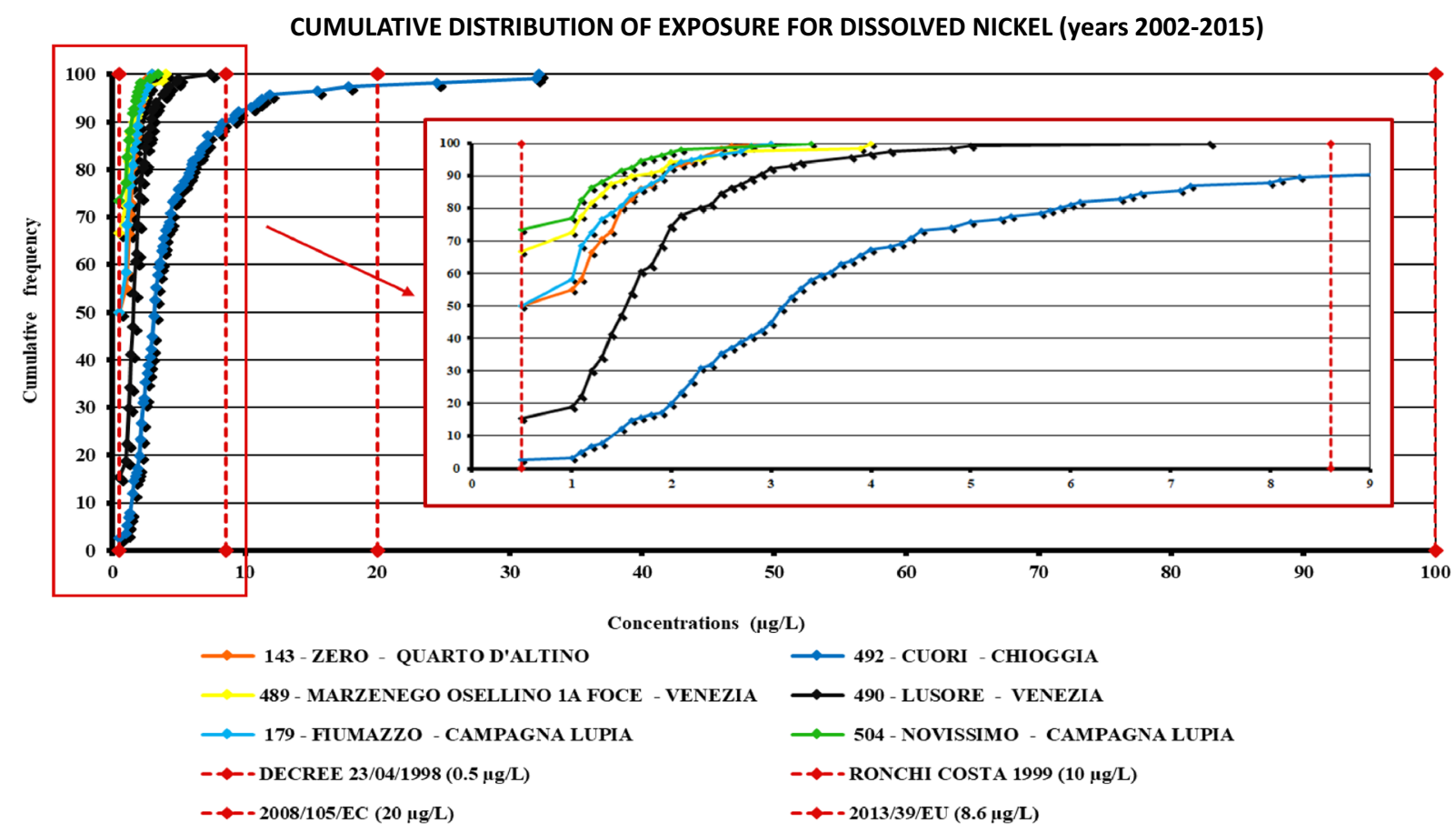

Fig. 7 Cumulative distribution of exposure (monthly averages from 2002 to 2015) for dissolved Ni versus local (Decrees 23/04/1998 and 30/07/1999) and EU (Decrees 2008/105/EC and 2013/39/EU) EQS 
where the measured values exceed reference EQS. For the dissolved and total form of As, the stations at a higher level of concern are the ones on the mouths of Lusore and Fiumazzo channels. Cr concentrations level may be considered low applying the discharge limit values established with the Italian Decree 30/07/1999 of $100 \mu \mathrm{g} / \mathrm{L}$. The most polluted station appears at the Cuori channel. Like in the As assessment, a basically stable trend is also defined for $\mathrm{Ni}$ and $\mathrm{Pb}$. For $\mathrm{Ni}$, Lusore and Cuori stations are at higher concern compared to the others. Concerning $\mathrm{Pb}$, among the most polluted stations, Lusore channel and Marzenego river are identified as the stations at most concern.

The EQSs and discharge limit values for the Venice Lagoon and its catchment area, as well as the acceptable loads for the lagoon, were defined by the National Institute for Health (ISS 1996) and by the National Research Council Water Institute (IRSA-CNR 1996). These studies were used to set up the special legislation on Venice Lagoon and its catchment. The local list of parameters, together with the EQSs for the Venice Lagoon catchment basin, was developed on the basis of a conservative risk analysis model concerning the protection of the entire ecosystem. A comprehensive approach was taken regarding the lagoon, based on the mass balance for each pollutant, estimated by taking into account the inflow and elimination processes and by studying a complete mixing model and the pollutant loads discharged over the past decades (Ostoich et al. 2009). The EQSs for the Venice Lagoon and its catchment were defined according to the background levels of the considered parameters in natural and not anthrophized areas and therefore according to a highquality class with reference to the Directive 2000/60/ EC. It can be concluded that for a routinely approach, the research of LOQ able to be pursuant with background levels appears to be excessive when the monitoring and verification of the good chemical status is guaranteed with the LOQs already achieved. Moreover, the EQSs for the Venice Lagoon's catchment are defined by the Italian Decree 23/04/1998 as guide values, therefore not compulsory as referred to the background level.

\section{Conclusions}

This study allowed to retrieve and handle data collected in the institutional monitoring activity by the Veneto Region (North Italy) Environmental
Regional Protection Agency over 15 years (20002015). Six trace elements have been considered (As, $\mathrm{Cd}, \mathrm{Cr}, \mathrm{Hg}, \mathrm{Ni}, \mathrm{Pb}$ ) with statistical and graphical assessment, in order to assess the correct implementation of the Directive 2000/60/EC and the comparison with the existing standards for the Venice Lagoon (special legislation). In the considered period limits of quantification (LOQs) of the methods, they were improved according to the requirements of European regulations and the update of analytical techniques. From the data analysis performed, it is evident that at the beginning for some parameters like $\mathrm{Ni}$ and $\mathrm{Cr}$ the situation appeared not satisfactory, as many data were below LOQs and the same limits were not always able to appreciate the EQS for surface waters neither the discharge limit value. For other parameters like As, the LOQ was appropriate since the beginning of the monitoring period, while for $\mathrm{Hg}$, a satisfactory LOQ for the very strict local legislation is still a challenge. Suitable analytic procedures applied at routinely level appear of utmost importance in water monitoring.

From temporal trends, improvements for water quality have been observed in parameter of anthropic origin (the case for example of Ni or $\mathrm{Cr}$ ). For parameters like As, of high probable natural origin, in particular from groundwater that in lower Veneto plain can feed surface waters, the trend appears constant and with a periodicity. The quality improvement can be tied to the huge investments in wastewater treatment infrastructures as well as also to changes in economic productivity.

Cumulative frequency distributions have been also built for the most significant parameters. For all the obtained curves, it is clear that the assessment is conditioned by the LOQ level achieved with the available analytical technique. Cuore and Lusore channels appear the most critical water bodies in the Venice Lagoon catchment. According to preliminary descriptive statistical analysis, the available data appeared acceptable in comparison to EU standard values except for the station in Cuori Channel. This is not true if we consider the special local legislation on Venice catchment and the Lagoon and in particular considering the very low standards and limit values imposed. From monitoring in the first years of the considered period, it appears that there is no overtaking: it must be observed that in this period, LOQs of the applied analytical techniques were higher so detection in following years is not a sign of worsening of the water quality but of the improved analytical capacity. The polluting loads of the considered trace 
elements have been considered only to supply a preliminary assessment, leaving more specific consideration in further studies.

For the basin level of the Venice Lagoon, the EQS concentration values fixed by the Venice special legislation require the development of analytical methods which are not yet available or, where available, are not sufficiently sensitive and/or selective, with a decrease in the limit of the current methods of quantification by a factor of 10-100 for natural waters. The lesson we can learn is that data are important but they must be managed considering their quality and in particular the LOQs of the applied techniques. Comparison with standard values as screening approach is useful only where appropriate LOQs are available. Natural contribution to some elements can be of course an aspect to be appropriately assessed. Moreover, given its peculiarity, and the pressures insisting on it, the Venice Lagoon can be considered a pilot area for the development and application of specific environmental quality standards (EQS) to guarantee an ecological equilibrium also in presence of pollution loads.

Acknowledgments The authors want to thank the Interregional Department for OOPP Triveneto (formerly VWA, Venice Water Authority) belonging the Ministry of Infrastructure and Transport and Consorzio Venezia Nuova (CVN, VWA's unique concessionary) for providing the quantitative flow data of the selected water bodies. We are particularly grateful to $\mathrm{PhD}$ Lara Lamon of the University of Venice Ca' Foscari for the support in risk assessment.

\section{References}

Alharbi, T., \& El-Sorogy, A. (2017). Assessment of metal contamination in coastal sediments of Al-Khobar area, Arabian Gulf, Saudi Arabia. Journal of African Earth Sciences, 129, 458468. https://doi.org/10.1016/j.jafrearsci.2017.02.007.

Allan, R. (2012). Water sustainability and the implementation of the Water Framework Directive - a European perspective. Ecohydrology \& Hydrobiology, 12(2), 171-178. https://doi.org/10.2478/v10104-012-0007-1.

Batbayar, G., Pfeiffer, M., von Tümpling, W., Kappas, M., \& Karthe, D. (2017). Chemical water quality gradients in the Mongolian sub-catchments of the Selenga River basin. Environmental Monitoring and Assessment, 189(8), 420. https://doi.org/10.1007/s10661-017-6123-z.

Bernardello, M., Secco, T., Pellizato, F., Chinellato, M., Sfriso, A., \& Pavoni, B. (2006). The changing state of contamination in the Lagoon of Venice. Part 2: trace elements. Chemosphere, 64(8), 1334-1345. https://doi. org/10.1016/j.chemosphere.2005.12.033.
Cacciatore, F., Noventa, S., Antonini, C., Formalewicz, M., Gion, C., Berto, D., Gabellini, M., \& Brusà, R. B. (2016). Imposex in Nassarius nitidus (Jeffreys, 1867) as a possible investigative tool to monitor butyltin contamination according to the Water Framework Directive: a case study in the Venice Lagoon (Italy). Ecotoxicology and Environmental Safety. https://doi.org/10.1016/j.ecoenv.2015.12.039.

Carrer, S., Coffaro, G., Bocci, M., \& Barbanti, A. (2005). Modelling partitioning and distribution of micropollutants in the Lagoon of Venice: a first step towards a comprehensive ecotoxicological model. Ecological Modelling, 184, 83-101. https://doi.org/10.1016/j.ecolmodel.2004.11.019.

Cesa, M., Baldisseri, A., Bertolini, G., Dainese, E., Dal Col, M., Dalla Vecchia, U., Marchesini, P., \& Nimis, P. L. (2013). Implementation of an active 'biomonitoring' network for chemical status and temporal trend assessment under the Water Framework Directive in the Chiampo Valley's tannery district (NE Italy). Journal of Environmental Management, 114, 303-315. https://doi. org/10.1016/j.jenvman.2012.10.022.

Charizopoulos, N., Zagana, E., \& Stamatis, G. (2016). Hydrogeochemical investigations in a drained lake area: the case of Xynias basin (Central Greece). Environmental Monitoring and Assessment, 188(8). https://doi.org/10.1007 /s10661-016-5484-z.

Couto, C. M. C. M., Ribeiro, C., Maia, A., Santos, M., Tiritan, M. E., Ribeiro, A. R., Pinto, E., \& Almeida, A. (2018). Assessment of Douro and Ave River (Portugal) lower basin water quality focusing on physicochemical and trace element spatiotemporal changes. Journal of Environmental Science and Health - Part A Toxic/Hazardous Substances and Environmental Engineering, 1-11. https://doi.org/10.1080 /10934529.2018.1474577.

De Carvalho Aguiar, V. M., Abuchacra, P. F. F., Neto, J. A. B., \& de Oliveira, A. S. (2018). Environmental assessment concerning trace metals and ecological risks at Guanabara Bay, RJ, Brazil. Environmental Monitoring and Assessment, 190(8). https://doi.org/10.1007/s10661-018-6833-x.

Deheyn, D. D., \& Shaffer, L. R. (2007). Saving Venice: engineering and ecology in the Venice Lagoon. Technology in Society, 29, 205-213. https://doi.org/10.1016/j.techsoc.2007.01.014.

EC-European Commission (2000). Directive 2000/60/EC of the European Parliament and of the Council of 23 October 2000 establishing a framework for Community action in the field of water policy (Water Framework Directive), Official Journal of the European Communities L 327 22/12/2000.

EC-European Commission (2001). Commission Decision 2455/2001/EC of the European Parliament and of the Council of 20 November 2001 establishing the list of priority substances in the field of water policy and amending Directive 2000/60/EC, Official Journal of the European Communities L 331 15/12/2001.

EC-European Commission (2008) Directive 2008/105/EC of the European Parliament and of the Council of 16 December 2008 on environmental quality standards in the field of water policy, amending and subsequently repealing Council Directives 82/176/EEC, 83/156/EEC, 84/491/EEC, 86/280/ EEC and amending directive 2000/60/EC of the European Parliament and of the Council, Official Journal of the European Union L 348 24/12/2008. 
EC-European Commission (2009) Directive 2009/90/EC of 31 July 2009 laying down, pursuant to Directive 2000/60/EC of the European Parliament and of the Council, technical specifications for chemical analysis and monitoring of water status, Official Journal of the European Union L 201 01/08/2009.

EU-European Union (2013) Directive 2013/39/EU of the European Parliament and of the Council of 12 August 2013 amending Directives 2000/60/EC and 2008/105/EC as regards priority substances in the field of water policy. Official Journal of the European Union L 226 24/08/2013.

Giusti, L., \& Zhang, H. (2002). Heavy metals and arsenic in sediments, mussels and marine water from Murano (Venice, Italy). Environmental Geochemistry and Health, 24, 47-65.

Granero, S., \& Domingo, J. L. (2002). Levels of metals in soils of Alcalá de Henares, Spain: human health risks. Environment International, 28, 159-164.

Guerzoni, S., Rossini, P., Sarretta, A., Raccanelli, S., Ferrari, G., \& Molinaroli, E. (2007). POPs in the Lagoon of Venice: budgets and pathways. Chemosphere, 67, 1776-1785. https://doi.org/10.1016/j.chemosphere.2006.05.085.

Härdle, W., Klinke, S., \& Rönz, B. (2015). Introduction to statistics: using interactive $M M *$ Stat elements. Berlin: Springer. https://doi.org/10.1007/978-3-319-17704-5.

IRSA-CNR (Italian National Institute for Research on Waters) 1996 Proposal for the assessment of the admissible loads and the fixation of limit values for discharges for the Venice Lagoon and its catchment basin. Technical document prepared by IRSA-CNR for the drafting of the Italian Decree 23/ 04/1998 of the Italian Ministry of the Environment.

ISO 5667:3:1994 (1994) Water quality - sampling - part 3: guidance on the preservation and handling of samples, https://www.iso.org/standard/11766.html. Accessed 6/09/18.

ISO-IEC 17025:2005 (2005) General requirements for the competence of testing and calibration laboratories, https://www.iso.org/standard/39883.html. Accessed 4/10/17.

ISS (Italian National Institute for Health) (1996) Proposal of water quality objectives for the Venice Lagoon and its catchment basin. Technical document prepared by ISS for the drafting of the Italian Decree 23/04/1998 of the Italian Ministry of the Environment.

Italian Decree 23/04/1998 - Italian Ministry of the Environment. Waters quality requirements and characteristics of wastewater treatment plants for the protection of the Venice Lagoon, O.J. 18/06/1998 n. 140. http://www.reteambiente. it/normativa/1304/

Italian Decree 3/04/2006 n. 152. Regulation for environment protection. Ord. Suppl. n. 96 to Italian O.J. 14/04/2006 n. 88.

Italian Decree 30/07/1999 - Italian Ministry of the Environment. Limits on industrial and civil discharges into the Lagoon of Venice and water-bodies of its drainage basin, in accordance with point 5 of the DM 23/04/1998 concerning water quality requirements and characteristics of wastewater treatment plants for the protection of the Venice Lagoon, Suppl. O.J. 19/08/1999 n. 194.

Italian Decree 9/02/1999. Total maximum permissible loads of pollutants in the Venice Lagoon, O.J. 12/02/1999 n.35.

Italian Decree n. 962/1973 concerning the protection of the city of Venice and its territory by water pollution. O.J. 1/02/1974 n. 30 .
Lepom, P., Brown, B., Hanke, G., Loos, R., Quevauviller, P., \& Woolgast, J. (2009). Needs for reliable analytical methods for monitoring chemical pollutants in surface water under the European Water Framework Directive. Journal of Chromatography A, 1216, 302-315. https://doi.org/10.1016/j.chroma.2008.06.017.

Martí, N., Aguado, D., Segovia-Martínez, L., Bouzas, A., \& Seco, A. (2011). Occurrence of priority pollutants in WWTP effluents and Mediterranean coastal waters of Spain. Marine Pollution Bulletin, 62, 615-625. https://doi.org/10.1016/j. marpolbul.2011.01.010.

Masiol, M., Facca, C., Visin, F., Sfriso, A., \& Pavoni, B. (2014). Interannual heavy element and nutrient concentration trends in the top sediments of Venice Lagoon (Italy). Marine Pollution Bulletin, 89, 49-58. https://doi.org/10.1016/j. marpolbul.2014.10.036.

Micheletti, C., Critto, A., \& Marcomini, A. (2007). Assessment of ecological risk from bioaccumulation of PCDD/Fs and dioxin-like PCBs in a coastal lagoon. Environment International, 33, 45-55. https://doi.org/10.1016/j. envint.2006.06.023.

Micheletti, C., Gottardo, S., Critto, A., Chiarato, S., \& Marcomini, A. (2011). Environmental quality of transitional waters: the Lagoon of Venice case study. Environment International, 37, 31-41. https://doi.org/10.1016/j.envint.2010.06.009.

Migahed, F., Abdelrazak, A., \& Fawzy, G. (2016). Batch and continuous removal of trace elements from industrial effluents using microbial consortia. International Journal of Environmental Science and Technology. https://doi.org/10.1007/s13762-016-1229-3.

Nagy, A. S., Szabó, J., \& Vass, I. (2016). Evaluation of trace metal levels in surface water and sediments of the Hungarian upper section of the Danube River and its tributaries. Journal of Environmental Science and Health - Part A Toxic/Hazardous Substances and Environmental Engineering, 51(14), 12481261. https://doi.org/10.1080/10934529.2016.1212565.

Nesto, N., Romano, S., Moschino, V., Mauri, M., \& Da Ros, L. (2007). Bioaccumulation and biomarker responses of trace metals and micro-organic pollutants in mussels and fish from the Lagoon of Venice, Italy. Marine Pollution Bulletin, 55, 469-484. https://doi.org/10.1016/j.marpolbul.2007.09.009.

Ostoich, M., Critto, A., Marcomini, A., Aimo, E., Gerotto, M., \& Menegus, L. (2009). Implementation of Directive 2000/60/ EC: risk-based monitoring for the control of dangerous and priority substances. Chemistry and Ecology, 25(4), 257-275. https://doi.org/10.1080/02757540903103857.

Pastres, R., \& Solidoro, C. (2012). Monitoring and modeling for investigating driver/pressure-state/impact relationships in coastal ecosystems: examples from the Lagoon of Venice. Estuarine, Coastal and Shelf Science, 96, 2230. https://doi.org/10.1016/j.ecss.2011.06.019.

Pastres, R., Solidoro, C., Ciavatta, S., Petrizzo, A., \& Cossarini, G. (2004). Long-term changes of inorganic nutrients in the Lagoon of Venice (Italy). Journal of Marine Systems, 51, 179-189. https://doi.org/10.1016/j.jmarsys.2004.05.011.

Pavoni, B., Donazzolo, R., Marcomini, A., Degobbis, D., \& Orio, A. A. (1987). Historical development of the Venice Lagoon contamination as recorded in radiodated sediment core. Marine Pollution Bulletin, 18(1), 18-24. https://doi.org/10.1016/0025-326X(87)90651-5. 
Ridgway, J., Breward, N., Langston, W. J., Lister, R., Rees, J. G., $\&$ Rowlatt, S. M. (2003). Distinguishing between natural and anthropogenic sources of metals entering the Irish Sea. Applied Geochemestry, 18, 283-309.

Rodriguez, P., Méndez-Fernández, L., Pardo, I., Costas, N., \& Martinez-Madrid, M. (2018). Baseline tissue levels of trace metals and metalloids to approach ecological threshold concentrations in aquatic macroinvertebrates. Ecological Indicators, 91, 395-409. https://doi.org/10.1016/j. ecolind.2018.04.004.

Solidoro, C., Pastres, R., Cossarini, G., \& Ciavatta, S. (2004). Seasonal and spatial variability of water quality parameters in the Lagoon of Venice. Journal of Marine Systems, 51, 718. https://doi.org/10.1016/j.jmarsys.2004.05.024.

Solidoro, C., Bandelj, V., Aubry Bernardi, F., Camatti, E., Ciavatta, S., Cossarini, G., Facca, C., Franzoi, P., Libralato, S., Melaku, Canu, D., Pastres, R., Pranovi, F., Raicevich, S., Socal, G., Sfriso, A., Sigovini, M., Tagliapietra, D., \& Torricelli, P. (2010). Response of Venice Lagoon ecosystem to natural and anthropogenic pressures over the last 50 years in Hans Paerl and Mike Kennish, Coastal Lagoons: Systems of Natural and Anthropogenic Change, CRC Press, Taylor and Francis, 483-511.

Suter, G. W. (2000). Ecological risk assessment for contaminated sites. Lewis Publishers. Retrieved from https://www.crcpress.com/Ecological-Risk-Assessmentfor-Contaminated-Sites/Suter-II-Efroymson-SampleJones/p/book/9781566705257.
Vlachopoulou, M., Coughlin, D., Forrow, D., Kirk, S., Logan, P., \& Voulvoulis, N. (2014). The potential of using the Ecosystem Approach in the implementation of the EU Water Framework Directive. Science of the Total Environment, 470-471, 684-694. https://doi.org/10.1016/j. scitotenv.2013.09.072

Vystavna, Y., Frkova, Z., Celle-Jeanton, H., Diadin, D., Huneau, F., Steinmann, M., Crini, N., \& Loup, C. (2018). Priority substances and emerging pollutants in urban rivers in Ukraine: occurrence, fluxes and loading to transboundary European Union watersheds. Science of the Total Environment, 637-638, 1358-1362. https://doi.org/10.1016/j.scitotenv.2018.05.095.

Zatta, P., Gobbo, S., Rocco, P., Perazzolo, M., \& Favarato, M. (1992). Evaluation of heavy metal pollution in the Venetian lagoon by using Mytilus galloprovincialis as biological indicator. Science of the Total Environment, 119, 29-41. https://doi.org/10.1016/0048-9697(92)90253-O.

Zecchin, M., Brancolini, G., Tosi, L., Rizzetto, F., Caffau, M., \& Baradello, L. (2009). Anatomy of the Holocene succession of the southern Venice Lagoon revealed by very high-resolution seismic data. Continental Shelf Research, 29, 1343-1359. https://doi.org/10.1016/j.csr.2009.03.006.

Zonta, R., Costa, F., Collavini, F., \& Zaggia, L. (2005). Objectives and structure of the DRAIN project: an extensive study of the delivery from the drainage basin of the Venice Lagoon (Italy). Environment International, 31, 923928. https://doi.org/10.1016/j.envint.2005.05.002. 